\title{
Infections, inflammation and epilepsy
}

\author{
Annamaria Vezzani $^{1} \cdot$ Robert S. Fujinami $^{2} \cdot$ H. Steve White ${ }^{3} \cdot$ Pierre-Marie Preux $^{4,5,6}$. \\ Ingmar Blümcke $^{7} \cdot$ Josemir W. Sander $^{8,9} \cdot$ Wolfgang Löscher ${ }^{10,11}$
}

Received: 28 July 2015 / Revised: 18 September 2015 / Accepted: 20 September 2015 / Published online: 30 September 2015

(C) Springer-Verlag Berlin Heidelberg 2015

\begin{abstract}
Epilepsy is the tendency to have unprovoked epileptic seizures. Anything causing structural or functional derangement of brain physiology may lead to seizures, and different conditions may express themselves solely by recurrent seizures and thus be labelled "epilepsy." Worldwide, epilepsy is the most common serious neurological condition. The range of risk factors for the development of epilepsy varies with age and geographic location. Congenital, developmental and genetic conditions are mostly associated with the development of epilepsy in childhood, adolescence and early adulthood. Head trauma, infections of the central nervous system (CNS) and tumours may occur at any age and may lead to the development of epilepsy. Infections of the CNS are a major risk factor for epilepsy. The reported risk of unprovoked seizures in population-based cohorts of survivors of CNS infections from developed countries is between 6.8 and $8.3 \%$, and is much higher in resource-poor countries. In this review, the various viral, bacterial, fungal and parasitic infectious
\end{abstract}

Wolfgang Löscher

wolfgang.loescher@ tiho-hannover.de

1 Department of Neuroscience, IRCCS-“Mario Negri” Institute for Pharmacological Research, Milan, Italy

2 Department of Pathology, University of Utah, Salt Lake City, UT, USA

3 Department of Pharmacology, University of Utah, Salt Lake City, UT, USA

4 INSERM UMR1094, Tropical Neuroepidemiology, Limoges, France

5 Institute of Neuroepidemiology and Tropical Neurology, School of Medicine, University of Limoges, Limoges, France

6 Center of Epidemiology, Biostatistics, and Research Methodology, CHU Limoges, Limoges, France diseases of the CNS which result in seizures and epilepsy are discussed. The pathogenesis of epilepsy due to brain infections, as well as the role of experimental models to study mechanisms of epileptogenesis induced by infectious agents, is reviewed. The sterile (non-infectious) inflammatory response that occurs following brain insults is also discussed, as well as its overlap with inflammation due to infections, and the potential role in epileptogenesis. Furthermore, autoimmune encephalitis as a cause of seizures is reviewed. Potential strategies to prevent epilepsy resulting from brain infections and non-infectious inflammation are also considered.

Keywords Seizures $\cdot$ Epileptogenesis $\cdot$ Central nervous system $\cdot$ Cytokines $\cdot$ Meningitis $\cdot$ Encephalitis . Neuroinfectiology $\cdot$ Virus $\cdot$ Bacteria $\cdot$ Fungi $\cdot$ Parasites

7 Department of Neuropathology, University Hospital Erlangen, Erlangen, Germany

8 NIHR University College London Hospitals Biomedical Research Centre, UCL Institute of Neurology, London WC1N £BG, UK

9 Stichting Epilepsie Instellingen Nederland (SEIN), Heemstede, The Netherlands

10 Department of Pharmacology, Toxicology, and Pharmacy, University of Veterinary Medicine, 30559 Hannover, Germany

11 Center for Systems Neuroscience, Hannover, Germany 


\section{Introduction}

Worldwide, epilepsy is the most common serious neurological condition [80]; at least $40 \%$ of all epilepsies have structural or metabolic causes as a consequence of diverse brain injuries (see Table 1 for definitions of terms). Infections and infestations are among the most common risk factor for seizures and acquired epilepsy [2, 3, 98, 124], and are probably the most common preventable risk factor for epilepsy worldwide, particularly in resource-poor settings $[118,124]$. Of the estimated 70 million people with epilepsy, 60 million live in low- or medium-income countries and about half of these are children [97]. People of any age may develop seizures due to infections ranging from toxoplasma in the newborn, early childhood infection with human herpesvirus (HHV)-6 to Creutzfeldt-Jakob disease (CJD) in the elderly [52]. Seizures may be the only presenting symptom of an infestation such as neurocysticercosis (NCC) or may be one symptom of global central nervous system (CNS) dysfunction, such as in subacute sclerosing panencephalitis or rabies [52].

It is important to differentiate between early seizures, which may occur within the first 1-2 weeks after infection [14] and late unprovoked seizures, which occur later (often months to years) after infection and are therefore defined as acquired epilepsy (Fig. 1) [76]. Early seizures (also termed acute symptomatic, provoked, or insult-associated seizures), which occur at or soon after the time of a systemic insult, occur in up to $30 \%$ of all CNS infections $[14,124]$ and are not considered spontaneous seizures; they are thought to be mechanistically different from any subsequent consequential chronic epilepsy [122]. Early seizures are a risk factor for the later development of epilepsy, although not all people with early seizures will develop late seizures and not all those with late seizures have early seizures [76]. We currently do not know risk factors for the development of epilepsy following early seizures. It is not possible to ascertain whether such early seizures are

Table 1 Glossary of terms used in this review

Term Definition

Antiepileptic (now often replaced by the term "anti-seizure")

Antiepileptogenic

Early seizures

Epilepsy

Aetiology of epilepsy

Epileptogenesis

Late seizures

Latent period

Seizure
Symptomatic suppression of epileptic seizures

Counteracting the effects of epileptogenesis, including prevention, disease modification, and cure

Seizures occurring in the first 1-2 (occasionally 4) weeks after brain injury. Early seizures are typically felt to represent acute symptomatic (i.e. insult-associated, provoked) seizures, with the patient not qualifying as having epilepsy

A disease of the brain defined by any of the following conditions: (1) at least two unprovoked (or reflex) seizures occurring $>24 \mathrm{~h}$ apart; (2) one unprovoked (or reflex) seizure and a probability of further seizures similar to the general recurrence risk (at least $60 \%$ ) after two unprovoked seizures, occurring over the next 10 years; (3) diagnosis of an epilepsy syndrome [50]

The current concept for terminology and underlying cause is (1) genetic, (2) structural/metabolic, and (3) unknown, which replace the previously used terms idiopathic, symptomatic, and cryptogenic [15]. Epilepsies resulting from infections or infestations therefore belong to the structural/metabolic category. Other main causes of structural/metabolic epilepsies are traumatic brain injury, stroke, and brain tumours

A process of structural and functional changes transforming the normal brain to one that can generate abnormal neuronal activity that subserves spontaneous recurrent seizures. Furthermore, a more recent definition of epileptogenesis includes progression of the disease after the first seizure has occurred [106]

Spontaneous (unprovoked) seizures occurring later (often months or years) than early seizures (see "early seizures"). Mechanisms of early and late seizures are thought to differ. Late seizures are the clinical onset of acquired epilepsy

A widely held concept suggesting that after a brain injury occurs, there is frequently a "latent period" lasting months or years in which seizures do not occur, followed by the development of remote symptomatic epilepsy. During this period, epileptogenic changes occur in the structure and physiology of the brain that result in the development of epilepsy (see 'epileptogenesis')

An abnormal, hypersynchronous discharge of a population of neurons in the brain, which produce a variety of transient symptoms during clinical seizures, but can also be nonconvulsive and clinically unapparent (electrographic or subclinical seizures) 
Fig. 1 Steps in the development and progression of temporal lobe epilepsy and possible therapeutic interventions. The term epileptogenesis includes processes that take place before the first spontaneous seizure occurs to render the epileptic brain susceptible to spontaneous recurrent seizures and processes that intensify seizures and make them more refractory to therapy (progression). The concept illustrated in the figure is based on both experimental and clinical data. Adapted from Löscher et al. [78]

\section{Steps in epilepsy development, progression and intervention}

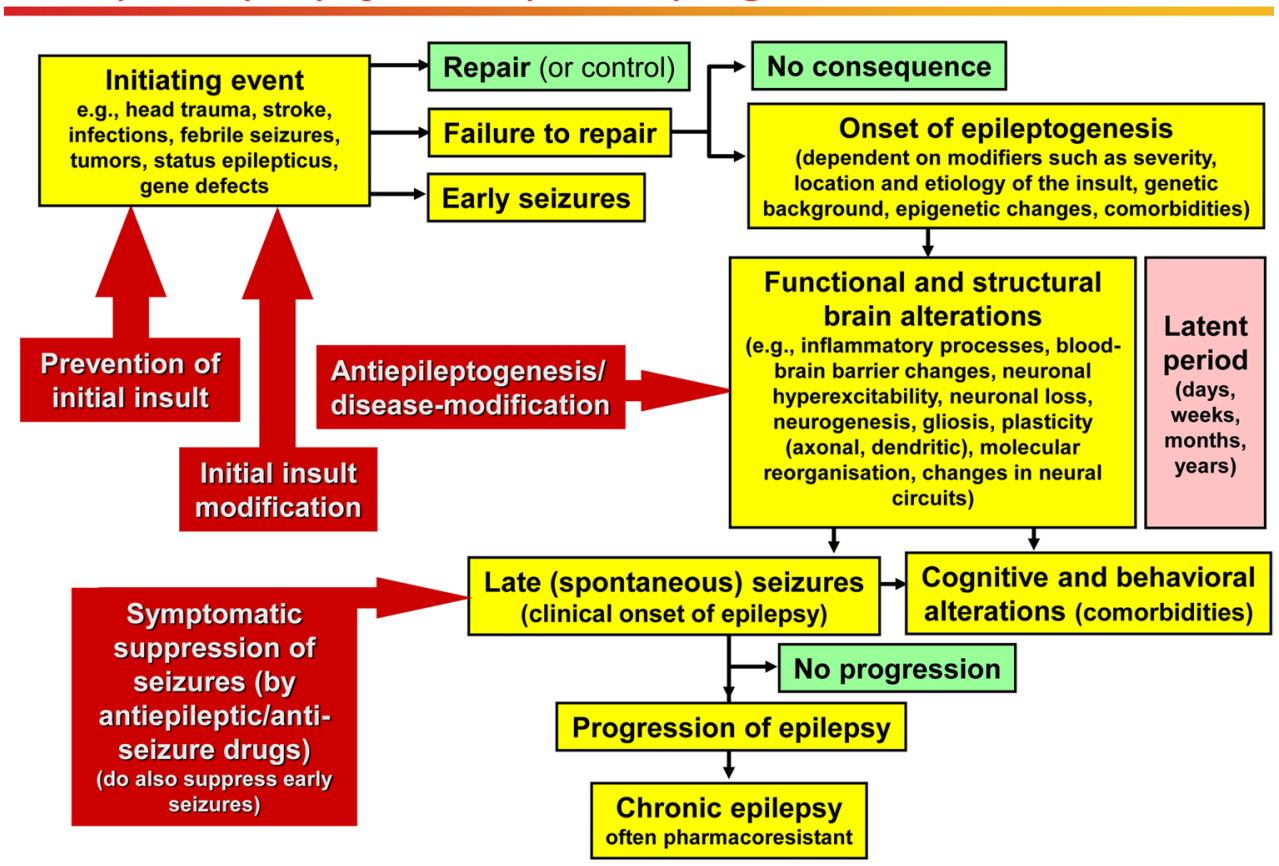

provoked (insult-associated) or are the first spontaneous seizures, indicating an early onset of epilepsy.

Infections may also induce status epilepticus, defined as one continuous, unremitting seizure lasting longer than $5 \mathrm{~min}$, or recurrent seizures without the person returning to a normal state between them [75]. Status epilepticus is a life-threatening neurological and medical emergency with high mortality, even with prompt pharmacological intervention [75]. A wide variety of CNS infections, including bacterial (e.g. typical bacterial meningitis, tuberculosis), viral (e.g. herpes simplex, HHV-6), parasitoses (e.g. cerebral toxoplasmosis, NCC, malaria), fungal (e.g. candidiasis, coccidioidomycosis, aspergillosis), and prion infections (CJD), can lead to status epilepticus [77]. When status epilepticus occurs with encephalitis it has a worse prognosis than those due to other aetiologies [77]. Autoimmune encephalitis is increasingly recognised as a cause of status epilepticus where no infectious organism is identified $[52,77]$.

Early seizures and status epilepticus in response to infections are both often insult-associated, occurring in close temporal proximity to the infection, while epilepsy with spontaneous recurrent seizures developing later results from a process termed "epileptogenesis" (Fig. 1) [106]. The risk of developing epilepsy after infections depends on the infectious agent, the severity of brain injury, age, genetic factors, and many other variables that are incompletely understood [89]. The reported risk of unprovoked seizures in population-based cohorts of survivors of CNS infections from developed countries is between 6.8 and $8.3 \%$, but is much higher in resource-poor settings [2, 124]. During the latent phase between infection and onset of epilepsy, various brain alterations occur, including impairment of blood-brain barrier (BBB) integrity, neuronal hyperexcitability, neuronal loss and gliosis, molecular and structural reorganisation, and epigenetic reprogramming, which ultimately may result in spontaneous recurrent epileptic seizures (Fig. 1) [79].

Here, we discuss first the aetiological factors comprising the various bacterial, parasitic, fungal and viral infections of the CNS which can result in seizures and epilepsy; second, we review the pathogenesis of epilepsy caused by brain infections, and the role of experimental models to investigate the mechanisms of epileptogenesis induced by infectious agents by focusing on the common inflammatory components shared by these pathologies that are triggered by different aetiological factors. Seizures may be induced by brain alterations in response to neurotropic infectious agents that target the CNS (which may include immune/ inflammatory-mediated responses intrinsic to the infected brain tissue). They may, however, also result from immune responses to systemic (non-CNS) infections resulting in, among other changes, proinflammatory cytokine-induced alterations in BBB integrity and subsequent neuronal hyperexcitability (Fig. 2) [83].

A further issue of this review is the sterile inflammatory response that occurs following various brain insults in the absence of an infectious agent, and is characterised by molecular mechanisms and pathways activation that often overlap with those induced by infections [137]. These 
Fig. 2 Interactions of infectious agents and the central nervous system

\section{The Central Nervous System and Infectious Disease}

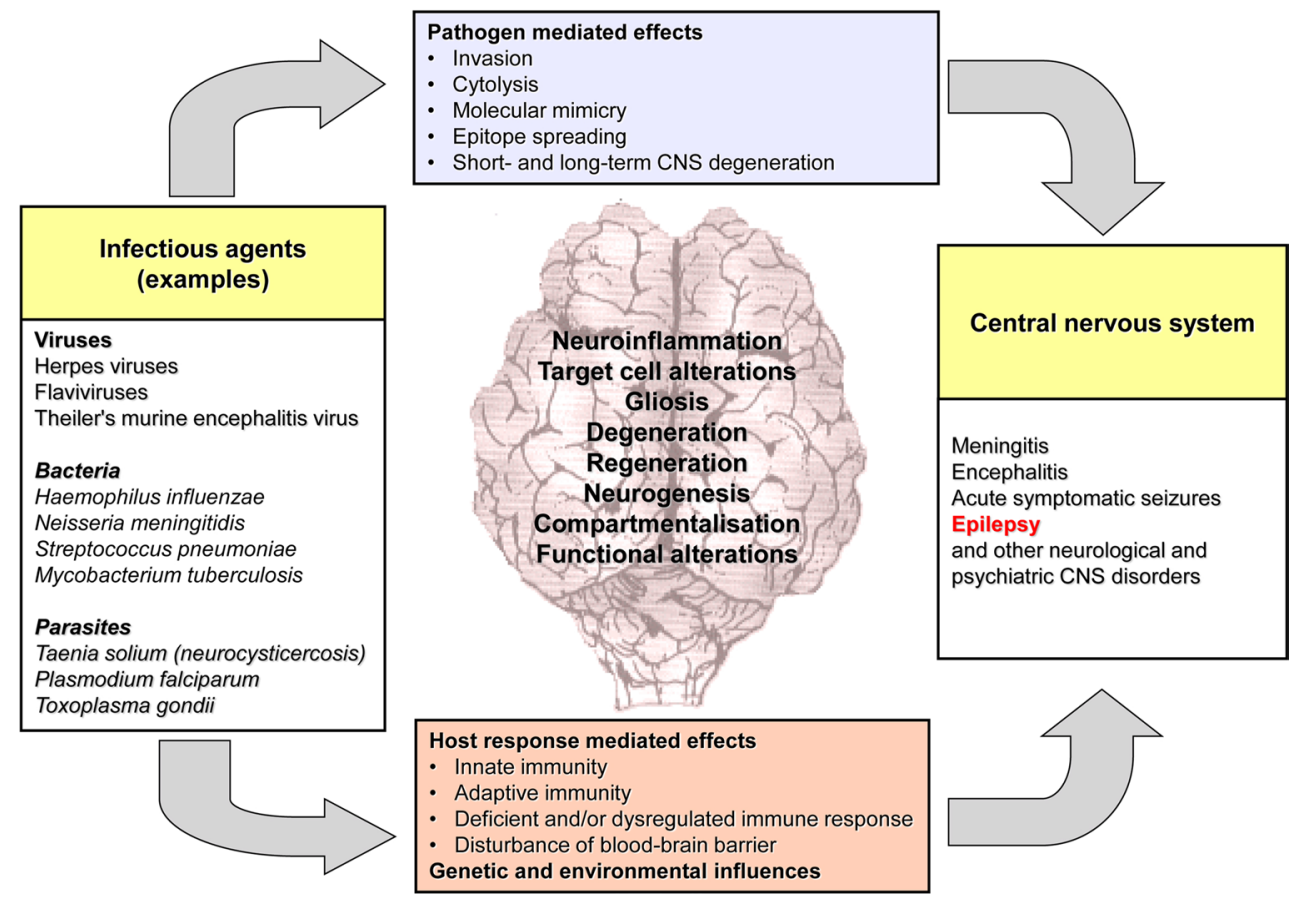

commonalities highlight the possibility that both infectious and sterile inflammation share common mechanisms with a potential role in epileptogenesis as suggested by experimental models [139] (Fig. 3). Potential strategies to prevent epilepsy resulting from brain infections and non-infectious inflammation are also briefly discussed.

\section{Bacterial infections as a cause of epilepsy}

Bacterial infections of the CNS involve mainly the meninges and the cerebral parenchyma; almost any CNS bacterial infection can result in acute symptomatic seizures and later acquired epilepsy [19, 38, 118, 119]. Those CNS infections which lead to empyemas and abscesses are particularly associated with the subsequent development of epilepsy although acute bacterial meningitis is also a culprit [3].

CNS infections present particular problems, as the $\mathrm{BBB}$, cerebrospinal fluid, meninges and immunological characteristics of the CNS create a unique environment $[118,119]$. The risk of seizures occurring seems modified by age at the infection as well as the presence of a family history of epilepsy, suggesting that genetic factors and brain maturation may play a role. The route of entry of the infective agent to the CNS space may be haematogenousthrough the BBB or the choroid plexus - or by direct invasion through trauma or from the cranial sinuses [118]. For seizures to develop, the infectious agent needs to reach or to damage the cerebral cortex. The full pathogenesis of both acute symptomatic seizures and acquired epilepsy after bacterial CNS disease is, however, unknown but is likely to involve arteritis, ischaemia and infarction triggering defence mechanisms with consequent inflammatory changes [38, 119].

The treatment of acquired epilepsy as a result of infections of the CNS follows the same principles as treatment of epilepsy due to other causes and antiepileptic drugs are the mainstay of treatment. The majority of epilepsy occurs in the aftermath of the infection, and there is usually no need to instigate antibiotic treatment at this time (although this is paramount during the acute phase of the infection) [118].

\section{Acute bacterial meningitis}

Acute symptomatic seizures and the late development of epilepsy in survivors of acute bacterial meningitis are well known, although there have been few attempts to characterise the risk of seizures according to the infective agent [19]. It is clear that infective agents vary with the age and the immune state of the individual, and with the route of entry. In the majority of cases of meningitis, the route of entry seems haematogenous from an infectious site elsewhere. Acute symptomatic seizures have been reported to occur in $10 \%$ of people with meningitis due to $N$. meningitidis, in $25 \%$ due to D. pneumonia, in $44 \%$ due to $H$. influenza and in $78 \%$ due to beta-haemolytic streptococcus infections $[19,38,118,119]$. These pyogenic organisms colonise the 


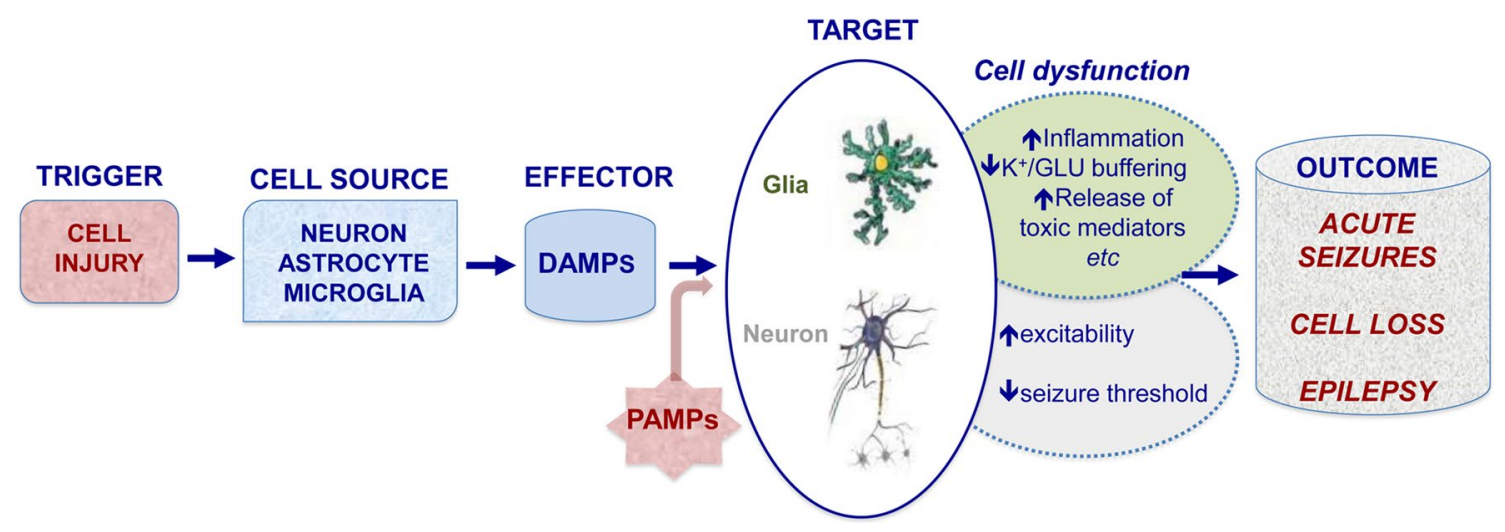

Fig. 3 Sequelae of pathological events induced by sterile inflammation and intersection with infection. The first event involved in sterile inflammation in the brain is a rapid outflow of damage-associated molecular patterns (DAMPs) from injured cells (cell sources: neurons and glia). The subsequent autocrine and paracrine activation of pattern recognition receptors (PRR, i.e. toll-like and NOD-like receptors) expressed by glia and neurons, the targeted cells in diseased tissue, leads to cell dysfunction. In particular, DAMPs induce transcriptional upregulation of inflammatory mediators in glia which contribute to the loss of extracellular $\mathrm{K}^{+}$, water and glutamate homeostasis, and promotes the release of toxic mediators such as reactive oxygen species, and gliotransmitters (e.g. D-serine, glutamate) activating neuronal glutamate receptors. Inflammatory molecules such

subarachnoid space producing a purulent exudate which, together with a direct effect of toxins they produce, may set up inflammatory reactions which are likely to be responsible for acute seizures and late epilepsy. These mechanistic aspects will be discussed in more detail later in this review.

Late (spontaneous) seizures, usually with focal characteristics and often drug resistant, will develop in between 5 and $10 \%$ of survivors of meningitis, usually with a short latency period (although this may vary from several weeks up to 9 years) [101]. People with neurological sequelae or with evidence of cerebral damage on neuroimaging seem at particularly high risk for the late development of acquired epilepsy which may be difficult to control, particularly in those with severe neurological damage $[38,85]$.

\section{Intracranial abscesses}

Cerebral abscesses (Figs. 4a, b, 5, 6) are usually associated with predisposing factors such as sinusitis, otitis media, dental abscess or congenital heart diseases $[19,38]$. The infective agents in about $50 \%$ of cases are anaerobic bacteria including Bacteroides, Fusobacterium, Prevotella and Actinomyces sp. [21]. Up to a quarter of cases will involve a mix of aerobic and anaerobic agents, and the remainder is due to aerobic organisms, particularly Haemophilus sp. Abscesses usually evolve over a couple of weeks causing localised encephalitis and arteritis before encapsulation [21]. This will usually trigger inflammatory processes in as IL- $1 \beta$, TNF- $\alpha$, IL- 6 and HMGB1 have pro-ictogenic properties in animal models and affect neuronal function by inducing rapid posttranslational changes in glutamate receptors subunit composition and/ or phosphorylation. These microenvironmental changes in concert contribute to neuronal network hyperexcitability and to reducing seizure threshold. Pathological outcomes then arise in the form of either acute symptomatic seizures, cell loss or development of epilepsy, or their combination. Pathogen-associated molecular patterns (PAMPs) pervading the brain tissue during infections can also activate PRR in neurons and glia, thereby triggering pathways overlapping with those activated by sterile inflammation, and provoking similar acute and long-term pathological consequences

the surrounding area and the development of acute seizures [38]. Localised damage resulting from the abscess itself and often from surgical drainage leads to gliosis, which will be the likely substrate for late seizures.

Acute symptomatic seizures are the presenting symptom of brain abscesses in up to a quarter of cases and over half of individuals will have such early seizures [21]. A high proportion of survivors, particularly of temporal abscesses, will later develop focal epilepsy, which is often drug resistant [38].

\section{Intracranial empyemas}

These are usually the consequence of direct spread of an adjacent focus of infection such as sinusitis or otitis media and are mostly caused by anaerobic agents. Pools of purulent material accumulate in subdural and epidural spaces [102]. These collections may distend the dura and cause thrombosis leading to localised encephalitis and arteritis and the consequent inflammatory response which is likely to be the substrate for seizures [38]. The great majority of people with empyemas will require surgical drainage and this may also increase the risk of acute seizures and subsequent epilepsy. There is a high risk of seizures during the acute phase of the empyema; survivors are likely to have neurological sequelae and up to a third will develop late seizures which are often drug resistant [23]. 

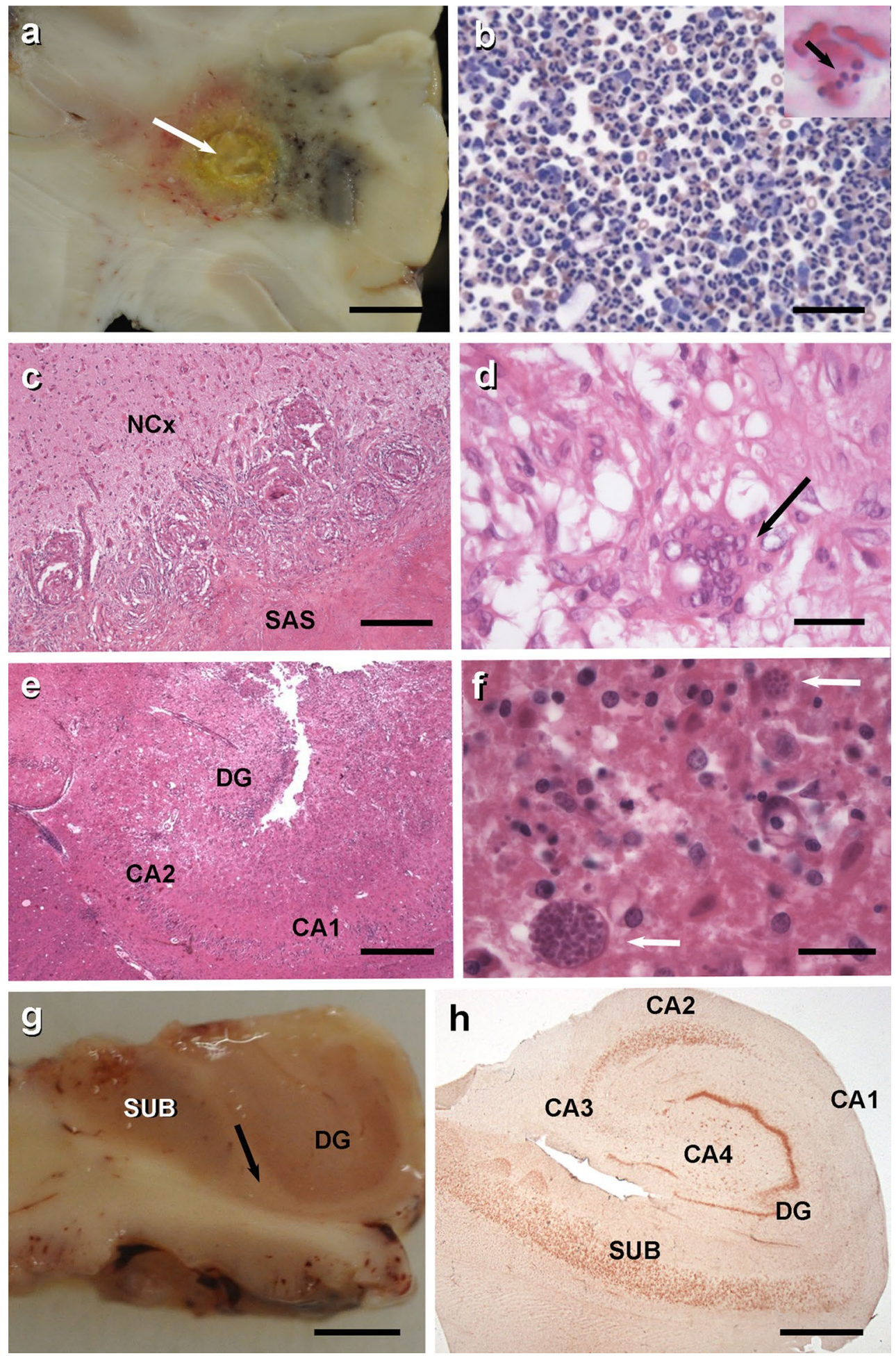

\section{CNS tuberculosis}

CNS tuberculosis (TB) is highly associated with epilepsy (Figs. 4c, d, 7), regardless of whether or not tuberculomas are apparent [19] and about $20 \%$ of people with CNS TB develop seizures. CNS TB is usually caused

by Mycobacterium tuberculosis which reaches the brain by the haematogenous route from the lungs [38]. The incidence of TB infection is increasing, particularly in areas in the developing world (such as sub-Saharan Africa) with a high incidence of HIV infection [118]. $\mathrm{TB}$ is becoming increasingly resistant to commonly used 
4 Fig. 4 a Frontal lobe abscess with purulent central necrosis and ill-defined haemorrhagic encephalitis. Scale $2 \mathrm{~cm}$. b Sedimentation of cerebrospinal fluid obtained from same patient revealed massive granulocytic infiltration (May-Grünwald-Giemsa staining, scale $20 \mu \mathrm{m}$ ). Inset demonstrates a macrophage with Gram-positive staphylococci (arrow). c 67-year-old male patient with epilepsy due to a cerebral tuberculoma (surgical tissue specimen; Mycobacterium tuberculosis was diagnosed by microbiological culture). Small granuloma were invading the neocortex ( $\mathrm{NCx}$ ). The subarachnoidal space (SAS) is occluded by large granuloma with central necrosis. Scale $200 \mu \mathrm{m}$. H\&E staining. d Rim of a typical granuloma with epithelioid and Langhans' cells (arrow). Scale $20 \mu \mathrm{m}, \mathrm{H} \& \mathrm{E}$ staining. e Patient with status epilepticus and toxoplasmosis with necrotic encephalitis affecting the right hippocampus ( $D G$ dentate gyrus; $C A 2 / C A 1$ regions of the cornu ammonis). Scale $200 \mu \mathrm{m}$. f Toxoplasma cysts with tachyzoites can be readily identified in H\&E stains (arrows). Scale $20 \mu \mathrm{m}$. g This 51-year-old patient suffered from right temporal lobe epilepsy since age 14 and underwent selective hippocampectomy. Thinning of the sclerotic CA1 region can be seen already by visual inspection (arrow indicates border between CA1 and subiculum/SUB). $D G$ dentate gyrus. Scale $2 \mathrm{~cm}$. h Darrow red staining of a $100 \mu \mathrm{m}$ thin vibratome section of the right hippocampus with segmental pyramidal cell loss in sectors CA1, CA3 and CA4 (hippocampal sclerosis ILAE type 1 [20])

chemotherapeutic agents. CNS TB may take the form of a subacute meningitis or intraparenchymal tuberculomas. Both forms have a high risk of seizures which are usually drug resistant $[19,38]$.

\section{Parasitic infections as a cause of epilepsy}

Almost all parasitoses can be associated with seizures and epilepsy (Table 2) either by a diffuse encephalitis or encephalopathy, or by intracerebral location of the parasite. In many resource-poor areas, there is no neuroimaging; thus serological detection remains the best way to detect parasites, combined with clinical and epidemiological
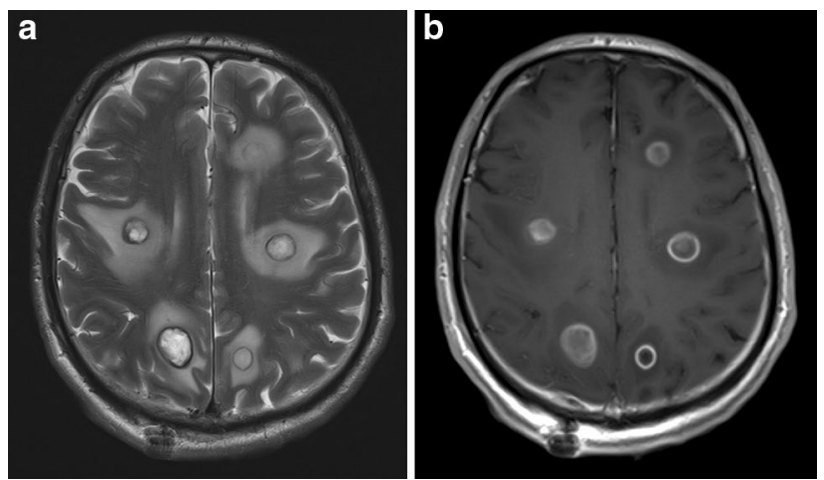

Fig. 6 Magnetic resonance imaging (MRI) of the brain in the axial plane demonstrating multiple heterogenous signalled lesions within the centra semiovale with associated surrounding vasogenic oedema on the T2-weighted (a) and predominantly peripheral enhancement on the post-contrast T1-weighted (b) sequences in the patient with embolic abscesses from bacterial endocarditis. Images contributed by Dr. Indran Davagnanam and Dr. Chandrashekar Hoskote, Consultant Neuroradiologists, Lysholm Department of Neuroradiology, The National Hospital for Neurology and Neurosurgery, Queen Square, United Kingdom

factors to suggest a diagnosis. Positive serology does not equate with active infection and it is very difficult to establish a causality link between parasitosis and disease in this context.

\section{Neurocysticercosis (NCC)}

Cysticercosis is the infestation by the larval form of Taenia solium, with pigs as the intermediate host [103]. It is a common neurological infestation and probably the major risk factor for acquired epilepsy in many African, Asian and Latin American countries. It is estimated that $30-50 \%$ of cases of epilepsy in endemic regions have the
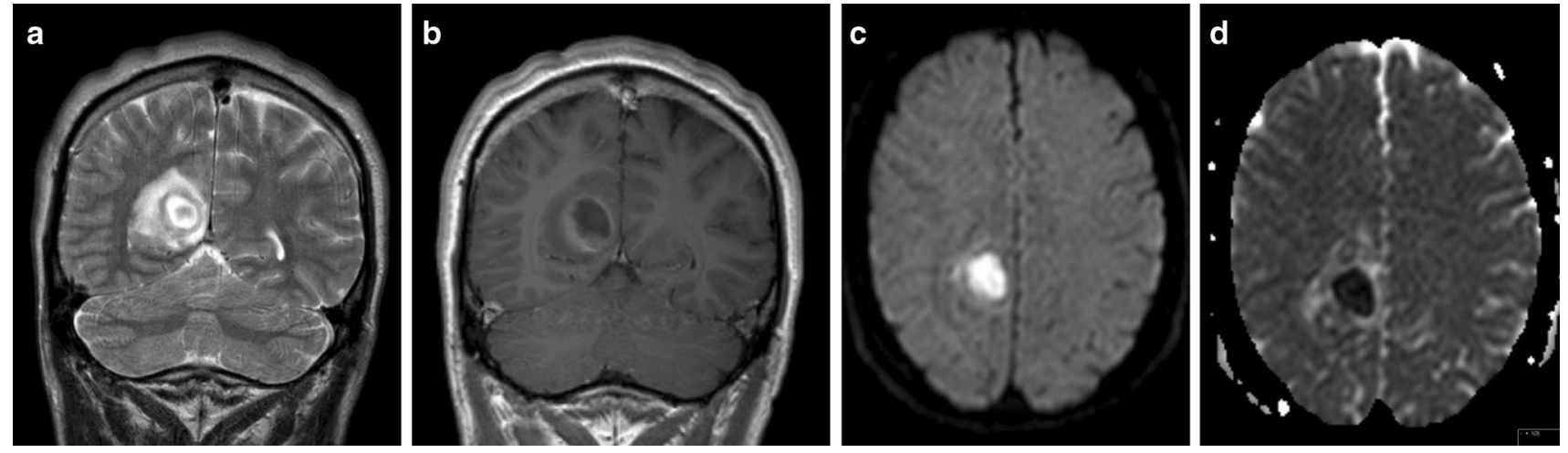

Fig. 5 Magnetic resonance imaging (MRI) of the brain in the coronal plane demonstrating a right parieto-occipital pyogenic abscess with surrounding vasogenic oedema on the T2-weighted sequence (a) and peripheral enhancement on the post-contrast T1-weighted sequence (b). Diffusion-weighted imaging demonstrates restriction on the trace B1000 sequence (c) and apparent diffusion coefficient maps (d). Images contributed by Dr. Indran Davagnanam and Dr. Chandrashekar Hoskote, Consultant Neuroradiologists, Lysholm Department of Neuroradiology, The National Hospital for Neurology and Neurosurgery, Queen Square, United Kingdom 

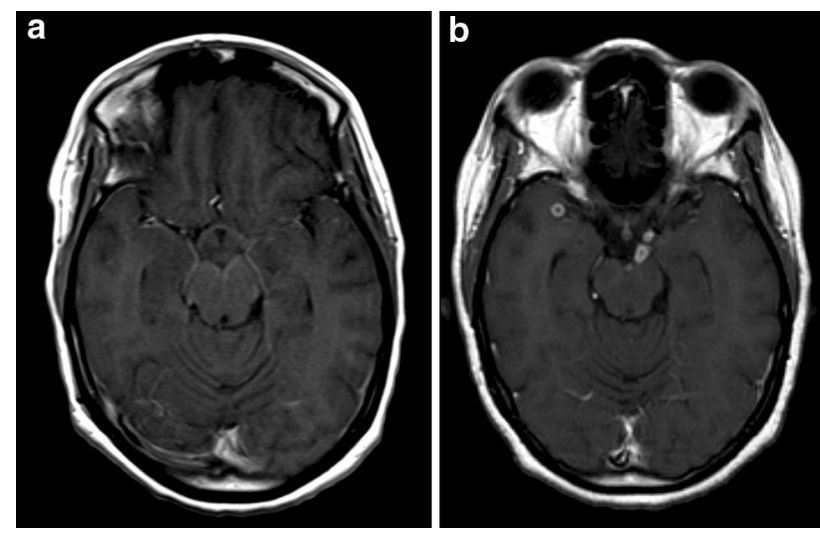

Fig. 7 Magnetic resonance imaging (MRI) of the brain in the axial plane demonstrating leptomeningeal enhancement on the post-contrast T1-weighted sequences at the basal cisterns in a patient with tuberculous basal meningitis (a). Peripherally enhancing tuberculous granulomas were seen approximately 3 weeks after the initial scan within the basal meninges on the follow-up post-contrast T1-weighted imaging (b). Images contributed by Dr. Indran Davagnanam and Dr. Chandrashekar Hoskote, Consultant Neuroradiologists, Lysholm Department of Neuroradiology, The National Hospital for Neurology and Neurosurgery, Queen Square, United Kingdom

neurological form of cysticercosis (Fig. 8) or NCC as a risk factor [24, 53, 109]. In sub-Saharan Africa, it is estimated that between 1.9 and 6.2 million people may have NCC, whilst in Latin America overall median $32.3 \%$ (95 \% CI 26.0-39.0) of people with epilepsy may have had NCC [146]. Significant associations between cysticercosis and epilepsy have been found in both Africa (OR 3.4, $95 \%$ CI 2.7-4.3) and Latin America (OR 2.8, $95 \%$ CI 1.9-4.0).

NCC is typically considered a disease of low- and medium-income countries but is increasingly diagnosed in the developed world. The rise in the number of cases of NCC diagnosed in the USA has largely been driven by the influx of immigrants from endemic regions [121]. Local transmission has also been documented particularly where there is a Taenia solium carrier in the household, confirming the relevance of NCC as a potential public health problem [121].

Epileptogenesis in cysticercosis may involve factors such as inflammation, oedema, gliosis and interaction with genetic factors. The host response to degenerating cysts may play an important role, and human NCC may offer a unique opportunity to understand basic mechanisms of seizures [93].

\section{Cerebral malaria}

Malaria is the most common tropical parasitic disease. CNS infection with Plasmodium falciparum may result in an acute encephalopathy (with febrile and acute seizures), which may be fatal or lead to polymorphic neurological sequelae. There is a clear association with epilepsy as a number of epidemiological studies in African endemic areas show [18, 94, 95, 98]. The most probable physiopathological mechanism is occurrence of vascular lesions due to cerebral malaria itself but interleukins involved in

Table 2 Parasitic diseases implicated in seizures and/or epilepsy

\begin{tabular}{ll}
\hline Protozoans & \\
Amoebiasis & Entamoeba histolytica, Naegleria fowleri, Acanthamoeba sp. \\
Malaria & Plasmodium falciparum \\
Toxoplasmosis & Toxoplasma gondii \\
Trypanosomiasis & Trypanosoma gambiense, Trypanosoma rhodesiense, Trypanosoma cruzi \\
Helminthiases & \\
Nematodoses & \\
Filariases & Wuchereria bancrofti, Brugia malayi, Loa loa, Dracunculus medinensis, Onchocercus volvulus \\
Trichinellosis & Trichinella spiralis \\
Toxocariasis & Toxocara canis, Toxocara cati \\
Angiostrongyliasis & Angiostrongylus cantonensis \\
Strongyloidosis & Strongyloides stercoralis \\
Trematodoses & \\
Schistosomiasis & Schistosoma japonicum, Schistosoma mansoni \\
Distomatosis & Fasciola hepatica \\
Paragonimiasis & Paragonimus westermani \\
Cestodoses &
\end{tabular}



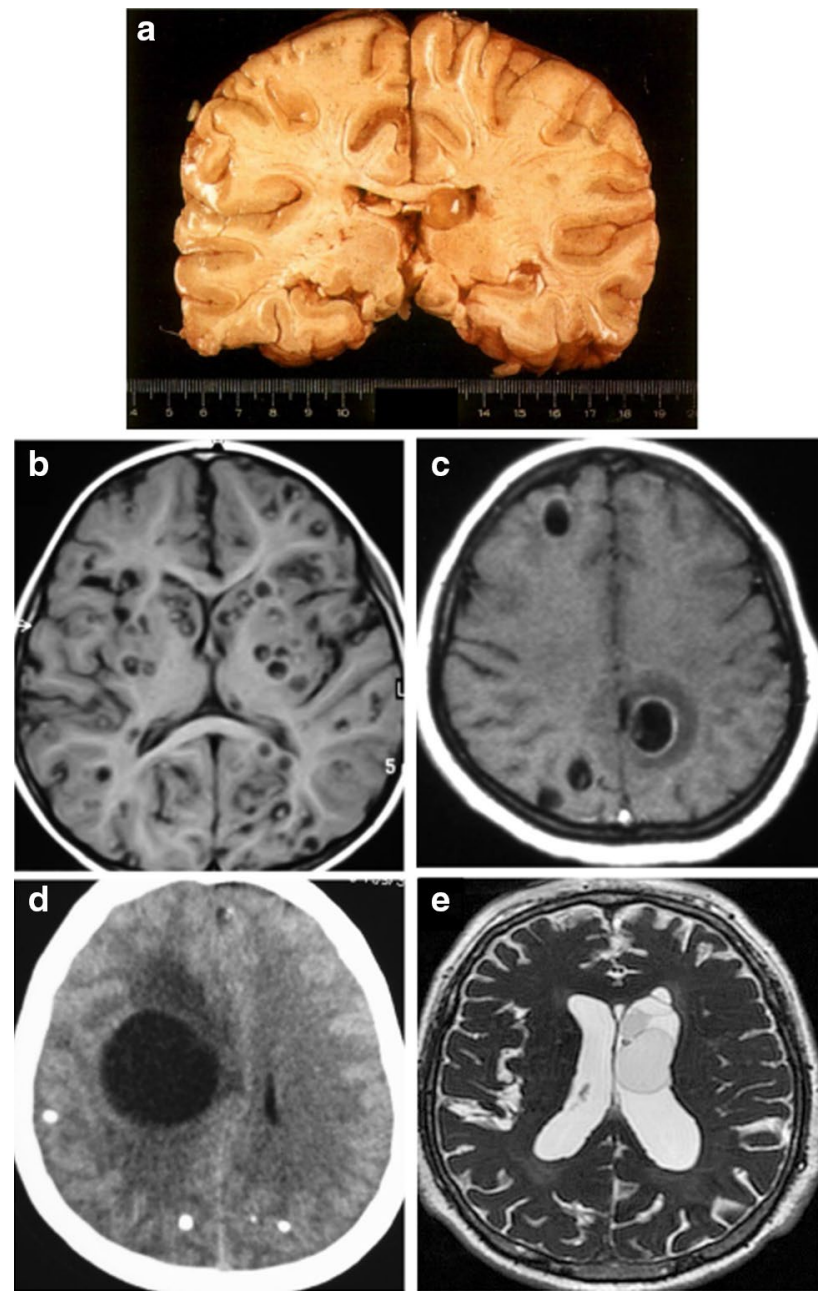

Fig. 8 Intra- and extraparenchymal neurocysticercosis (NCC). a Vesicular cyst containing a larva of Taenia solium in the left lateral ventricle (macroscopic view of a coronal brain section of a human autopsy case). Please note the absence of brain edema. The brain section was kindly provided by Prof. Thomas Henze (Reha-Zentrum Nittenau, Germany). b Viable cysts with scolex (MRI). c Viable and degenerative-choloidal cysts (MRI). d Viable cyst and many calcifications (CT scan). e Intraventricular cysts (MRI). MRI images were kindly provided by Dr. Arturo Carpio Rodas (School of Medicine, University of Cuenca, Cuenca, Ecuador)

inflammatory reaction could be involved, as in the generation of febrile seizures and epileptogenesis (Fig. 1).

\section{Onchocerciasis}

Onchocerciasis (Onchocerca volvulus filariasis which causes "river blindness") is endemic in large parts of West and Central Africa, as well as parts of Central and South America. It has been implicated as a potential risk factor for epilepsy due to the high prevalence of onchocerciasis in areas with a high prevalence of epilepsy. Analytical work on this association has produced conflicting results, perhaps related to confounders (other infections) or a lack of standardisation in methods. Recent meta-analyses showed significant associations with odds ratios around 2.5 or 3.0 [63, 105]. When the parasitological load is high, the prevalence of epilepsy seems higher. Three mechanisms have been considered: (i) presence of the larval form of the parasite in the CNS (usually infests skin and subcutaneous tissues and does not have easy access to the brain), (iii) host's immune response, (iii) sleep deprivation resulting from intense itching. Differential pathogenicity of strains may also play a role [84].

Onchocerciasis has also been suggested as causing nodding syndrome, an epileptic encephalopathy characterised by nodding of the head affecting mainly children in African regions endemic for onchocerciasis [31]. In several studies assessing the association with onchocerciasis, there is a trend towards higher positivity in cases than in controls [147] but this requires further investigations.

\section{Toxoplasmosis}

Toxoplasmosis is a common parasitic infection (Fig. 4e, f) affecting a third of the population world wide. It is an opportunistic infection among immunocompromised individuals, such as those with AIDS with a low CD4 cell count, in whom toxoplasmosis is a frequent cause of acute seizures and epilepsy. Chronic infection in immunocompetent people, usually considered asymptomatic, is suspected as a risk factor for various neurological disorders, including epilepsy. Few well-conducted studies are available; only six studies were identified in a systematic review [96], which estimated an OR of 2.2 (95\% CI 1.3-3.9). The likelihood of seizures is likely to be dependent on the number and location of cysts.

\section{Toxocariasis}

Human toxocariasis is the infestation caused by the larval stages of Toxocara canis and, less frequently, Toxocara cati. A systematic review evaluated the strength of association between epilepsy and Toxocara spp. and a recent update of this suggests that seropositivity for Toxocara spp. was significantly higher among people with epilepsy ([108] and Preux, unpublished results). The inclusion of prevalent rather than incident cases, however, does not allow the demonstration of a temporal relationship between exposure and outcome, and does not permit the exclusion of possible "reverse causality".

\section{Combination of parasites}

Concomitant infections are possible in areas endemic for several parasites. The degree of exposure to parasites and 
multiple parasitic infections may explain conflicting results obtained when only seropositivity is considered. In a recent study of people with active epilepsy, exposure to multiple infections was common [65]. Three quarters of cases with epilepsy and two-thirds of controls had been exposed to two or more infections. The combined effect of $T$. gondii and $O$. volvulus co-infection on the prevalence of epilepsy seemed more than additive.

\section{Fungal infections}

Seizures may also be a consequence of fungal CNS infections $[19,118,119]$. These were once a relatively rare occurrence but with the arrival of the AIDS epidemic and the widespread use of corticosteroids and cytotoxic agents, an increase of opportunistic CNS mycosis has been seen. They are still a relatively uncommon cause of seizures in fully immunocompetent people [119]. Fungal agents which may colonise the CNS and cause seizures include Candida, Cryptococcus, Coccidioides Aspergillus, Blastomyces, and Histoplasma. Candida affects mainly severely immunocompromised individuals or premature neonates. With the exception of Candida, which is part of the normal human biota particularly in the intestinal tract, most fungi gain entry by inhalation or through skin abrasions [118, 119]. Fungal infection of CNS can result in subacute or chronic basal meningitis, hyphal vasculitis leading to parenchymal abscesses, infarctions and granuloma formation, and capillary thrombosis independent of the infective agent [19]. Seizures may occur at any stage of the infections but those who survive tend to be at a high risk of late seizures.

\section{Viral infections as a cause of epilepsy}

Viral infection in humans can result in infection of the CNS. Viruses can disseminate via blood (viraemia/haematogenous route) or by neural pathways (axonal transport) into the CNS. Most viruses enter through peripheral routes such as skin and gastrointestinal or respiratory tracts and initially replicate locally at the site of entry, producing a viraemia. The virus is seeded to other sites within the body via the systemic circulation. It is during this initial seeding or following a systemic infection with secondary viraemia that virus can enter the CNS. Viruses can gain access by infecting mononuclear cells (Trojan horse) that enter the CNS or as particles that infect brain endothelial cells and are released into the parenchyma of the brain. A few viruses such as the herpes viruses and rabies virus are able to enter and infect peripheral neurons. Depending on the viral strain, virions or viral ribonucleoprotein complexes can be transported antegrade or retrograde within axons into the CNS, traversing synapses and infecting new neuronal cells. The act of viral replication within the CNS that results in inflammation of parenchymal CNS tissue is defined as encephalitis. This is in contrast to aseptic meningitis (inflammation of the meninges), without parenchymal involvement, caused by viral infection.

Once virus enters the brain parenchyma, inflammation can result from two mechanisms that are not mutually exclusive. First, viruses can directly infect neurons leading to neuronal lysis and death and the release of proinflammatory cytokines as well as cellular products acting as danger signals (such as ATP or mitochondria-derived DNA $N$-formyl peptides) [57, 145]. Second, these proinflammatory cytokines and danger signals can activate the innate immunity and, with time, the adaptive immune response, leading to immunopathology/damage. The two mechanisms probably work together to cause neuronal damage or dysfunction as discussed in more detail in the following sections. Virus infections can also trigger post-infectious encephalitis or encephalomyelitis, where autoimmune responses are generated which can result in autoimmune-mediated encephalitis mediated by T-cells and/or autoantibodies. $N$-methyl-D-aspartate receptor (NMDAR)-associated encephalitis, which mirrors many features of viral encephalitis [8, 39] will be discussed later in this review.

Different neurotropic viruses can cause encephalitis in humans (Fig. 9). Herpes viruses such as human herpes virus type 6 (HHV-6) have been associated with acute seizures and late acquired epilepsy. HHV-6 genomic DNA and protein are elevated in half of brain samples from the hippocampus of people with mesial temporal lobe epilepsy (TLE) [40]. TLE is the most common type of epilepsy in adult patients and is typically associated with hippocampal sclerosis (Fig. 4g, h) [28, 40]. HHV6B DNA was not detected in people with TLE without a history of encephalitis, but it was found in 5 of 9 CNS samples derived from people with TLE with encephalitis [99]. Recently, however, no differences in frequency of HHV-6B DNA between people with TLE and controls were found, although the virus load was lower in controls [47]. It has been reported that there is an association between HHV-6B infection and febrile status epilepticus (FSE) [44]. The "Consequences of Prolonged Febrile Seizures in Childhood" (FEBSTAT) study investigated HHV-6B and HHV-7 in FSE [44]. HHV-6B was more frequently associated with FSE than was HHV-7. The association with HHV-6B was mostly due to primary infection [44]. A different herpes virus, herpes simplex virus type-1 (HSV-1), can cause viral encephalitis. Thirty to $50 \%$ of individuals with HSV-1 encephalitis develop seizures [43, 90, 124]. Alphaviruses and Flaviviruses can be neurotropic and can cause encephalitis. Many of these 

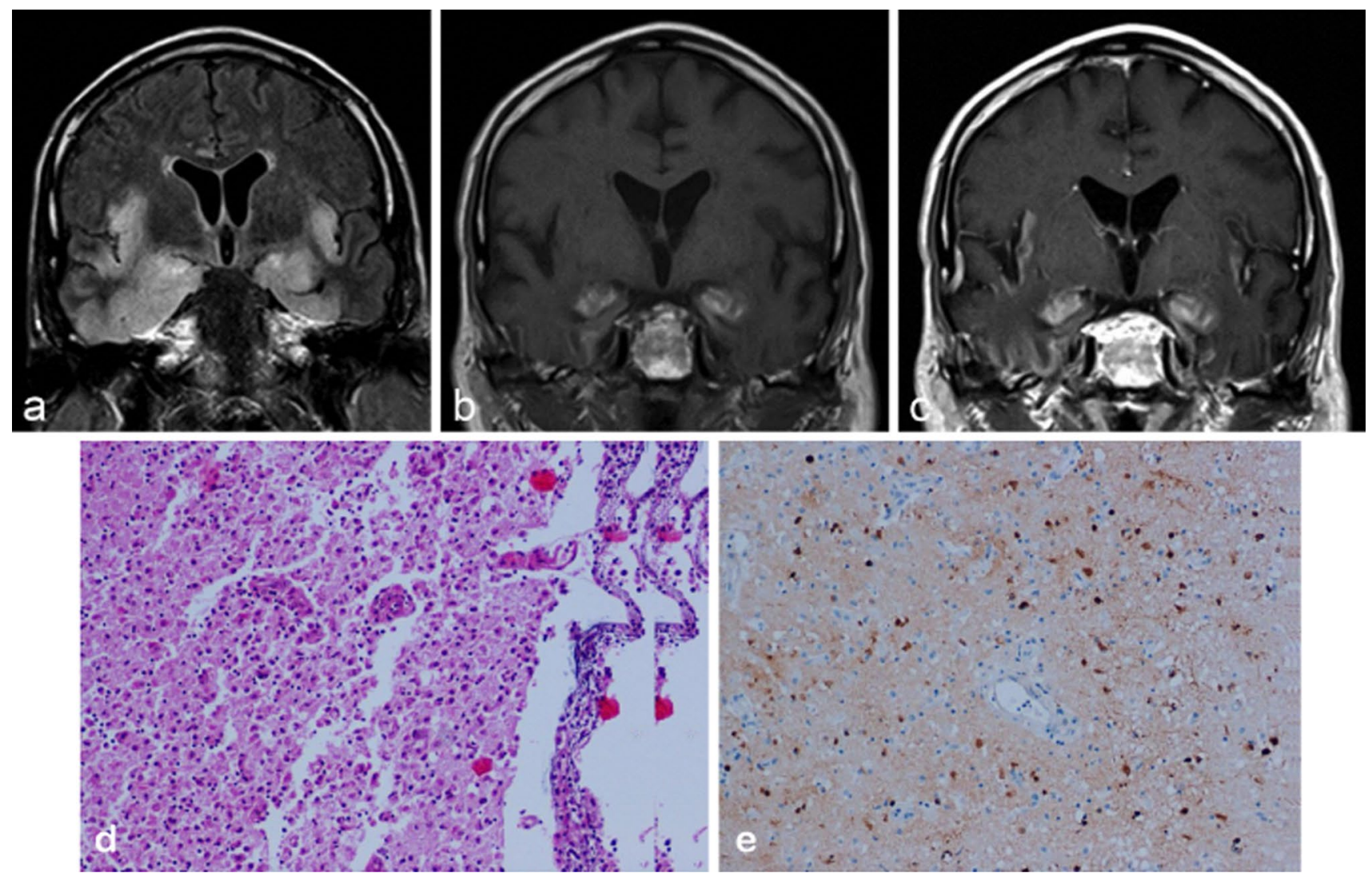

Fig. 9 Magnetic resonance imaging (MRI) of the brain in the coronal plane demonstrating signal hyperintensity and swelling on the FLAIR sequence involving the insula cortices, mesial and inferior temporal regions (a) in a patient with herpes simplex (HSV) encephalitis. There is associated T1-weighted hyperintensity within the mesial temporal structures on the pre-contrast T1-weighted imaging suggestive of haemorrhagic change (b), and some further enhancement on the post-contrast T1-weighted sequence $(\mathbf{c})$. MRI images contributed by Dr. Indran Davagnanam and Dr. Chandrashekar Hoskote, Consult-

viruses are transmitted via mosquitoes and, with global warming, are being found in more northern latitudes. For example, neuroinvasive cases of Eastern equine encephalitis virus (EEEV) have been increasing particularly in Eastern parts of the USA. Ten of 14 children admitted to hospital with EEEV had seizures [123]. Another mosquito-borne virus, Japanese encephalitis virus (JEV), is prevalent in Asia. Over half of children with JEV encephalitis reportedly have seizures, although the overall reported frequency is highly variable from under $10 \%$ to over $60 \%$ [90]. In India, $30 \%$ of children presenting with acute encephalitis syndrome were JEV positive [64] and over $80 \%$ of the children had seizures. West Nile Virus, another emerging virus associated with encephalitis and seizures, has spread across the USA since the late 1990s [124].

Viruses within the Picornaviridae Family, such as enteroviruses, Coxsackieviruses $\mathrm{A}$ and $\mathrm{B}$, parechoviruses and ant Neuroradiologists, Lysholm Department of Neuroradiology, The National Hospital for Neurology and Neurosurgery, Queen Square, United Kingdom. d Necrotizing HSV encephalitis with macrophage/ microglia infiltration in the cortex and meningeal inflammatory infiltrates $(H \& E \times 10)$. e Detection of HSV-infected neurons in the temporal cortex (immunohistochemistry for HSV, counterstained with haemalaun $\times 10$ ). Photomicrographs were kindly provided by Profs. Wolfgang Brück and Roland Nau (Institute of Neuropathology, Georg-August University, Göttingen, Germany)

echoviruses, have been associated with the development of febrile seizures. Enteroviruses are a leading cause of viral encephalitis in children. Cases of enterovirus-71 infection are increasing and infection can cause an acute flaccid paralysis similar to polio [73]. Approximately, $40 \%$ of children with a laboratory-confirmed viral infection were positive for either enterovirus or parechovirus infections, and about $45 \%$ of those individuals had prolonged seizures [133]. In another study, $42 \%$ of infants with enterovirus and $73 \%$ with parechovirus infection presented with severe seizures [134].

One hundred and twenty-six people with status epilepticus who presented in a neurological intensive care unit were evaluated [143]. Eighty-one $(64 \%)$ were classified as having non-refractory status epilepticus. Those with refractory status were more likely to have viral encephalitis $(31 \%)$ than those with non-refractory SE (6 \%) [143]. People with encephalitis are more likely to develop later 
seizures [15]. Following viral encephalitis complicated with acute seizures, there is a 22 -fold increase in developing unprovoked seizures [90]. This risk for seizures is most evident within the first 5 years after viral encephalitis.

\section{Experimental models to study mechanisms of epileptogenesis after brain infections}

Animal models are useful to study the mechanisms involved in infection-induced epileptogenesis, but most infectious agents that cause encephalitis in rodents are associated with high mortality, so that the processes leading to epilepsy cannot be investigated [72]. One exception is a recently developed animal model virus encephalitis that mirrors many of the features of viral encephalitisinduced epilepsy [69]. This has advantages over other earlier experimental animal models of virus-induced seizures and epilepsy. Rabbits, rats and mice have been infected with viruses and develop seizures, but most die following the acute viral encephalitis phase making the study of epilepsy limited [128]. C57BL/6 mice infected with Theiler's murine encephalomyelitis virus (TMEV) develop viral encephalitis with acute seizures (Fig. 10). Other mouse strains such as SJL/J, BALB/c and FVB/N did not develop seizures, but TMEV in SJL/J is widely used as a clinically relevant model of multiple sclerosis with mononuclear cell infiltration into the CNS and demyelination [129, 130]. In C57BL/6 mice, the peak of acute seizure activity occurs around 6 days post-infection (p.i.). Virus-infected cells are cleared by day 14 and viral genomes/virus by around day 28 p.i. TMEV has a predilection for CA1 hippocampal neurons and this region is lost either by bystander cell death or direct viral killing/infection after day 5 p.i. (Fig. 11b, c). Prior to and including day 5 , neuronal loss was minimal and similar between mice with seizures and mice without seizures. Following a variable latent period, mice develop spontaneous seizures/epilepsy [126]. Motor function and coordination were impaired in the animals with seizures [69] and mice demonstrated impaired cognitive ability and anxiety-like behaviours [132]. Since the acute seizures start at day 3 p.i., the role of the innate immune response to TMEV infection was examined. The innate immune system is made up of effector cells such as neutrophils, macrophages and natural killer (NK) cells. Brain resident innate immune cells include microglia and astrocytes. These cells can produce many proinflammatory cytokines that can contribute to the inflammation observed in the CNS. Complement is also a critical component of the innate immune response to infection. Fewer C57BL/6

\section{Mouse strain differences in responses to TMEV}

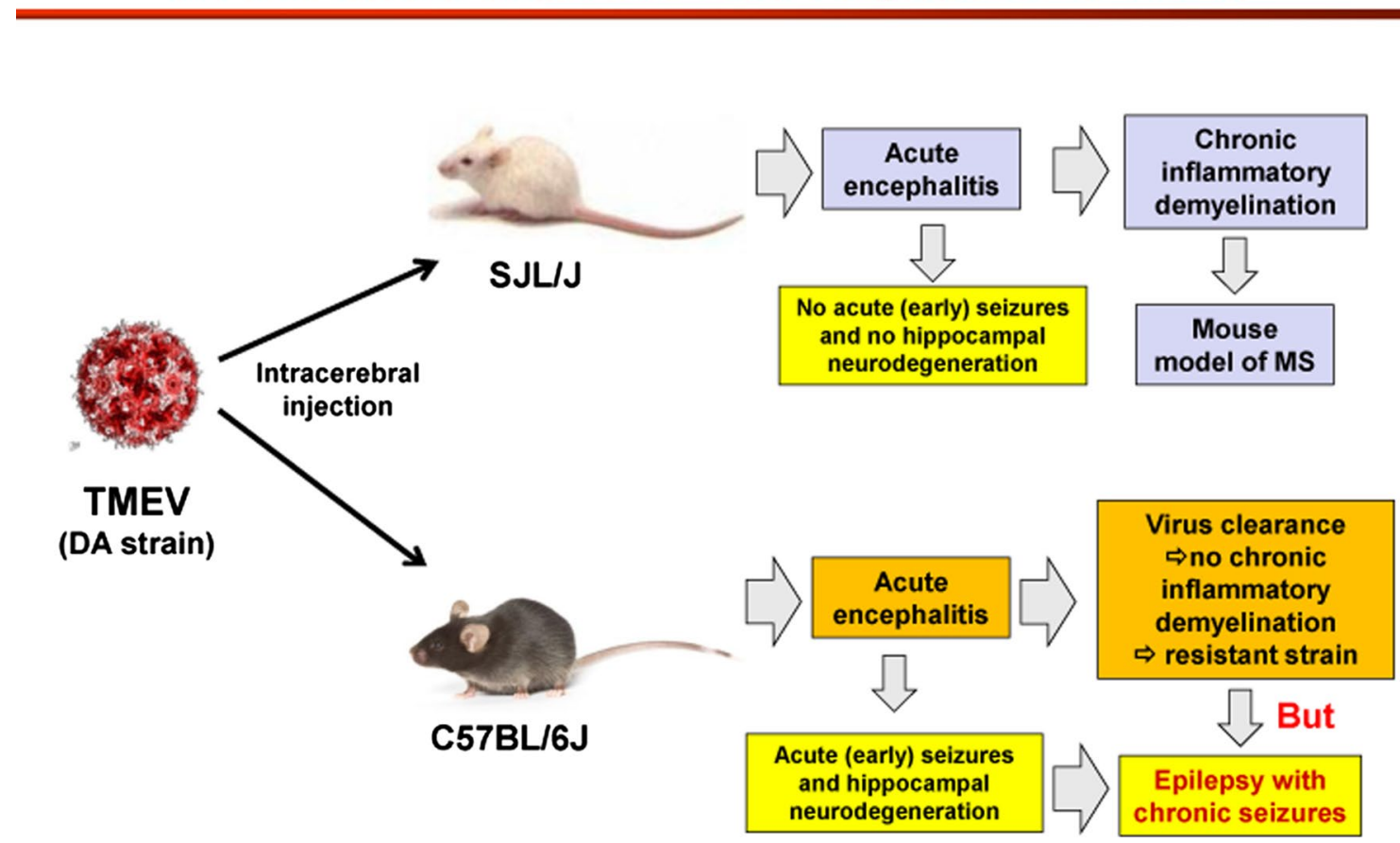

Fig. 10 Mouse strain differences in response to intracerebral infection with Theiler's murine encephalomyelitis virus (TMEV). While SJL/J mice exhibit mononuclear cell infiltration into the CNS and demyelination in response to the infection and are thus widely used as a model of multiple sclerosis (MS), C57BL/6J mice develop acute and late epileptic seizures and hippocampal damage reminiscent of temporal lobe epilepsy in humans 
a

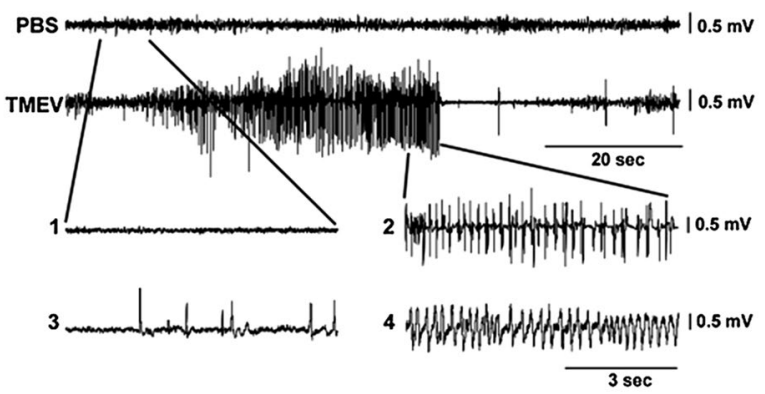

b
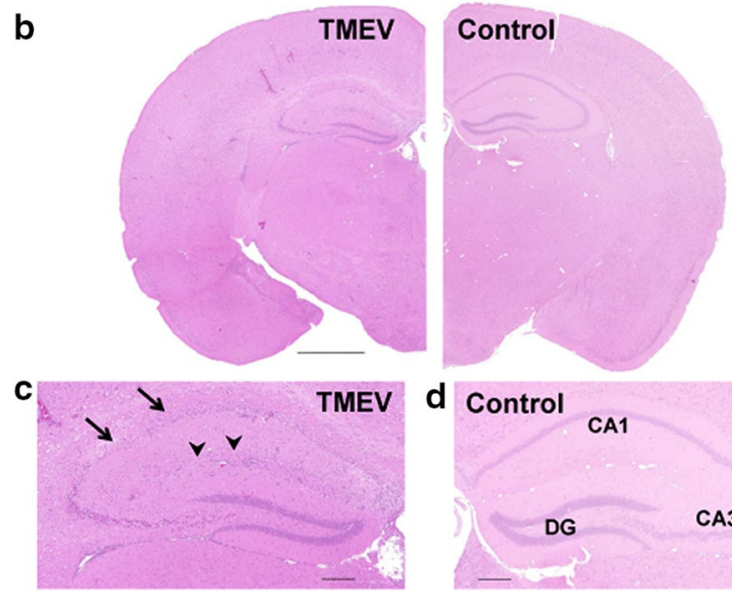

DG

CA3

Fig. 11 Representative electroencephalographic (EEG) epileptic events and hippocampal degeneration following Theiler murine encephalomyelitis virus (TMEV) infection in C57BL/6 mice. a Representative EEG traces (recorded via electrodes placed over the frontoparietal cortex) showing baseline activity in a control (PBS) mouse (top trace) compared with high-frequency, high-amplitude, and rhythmic paroxysmal activity recorded during a spontaneous generalised convulsive seizure at 4 months post-infection (p.i.) in an epileptic TMEV mouse. In the expanded traces [1-4], epileptic activity associated with behavioural arrest [3] or no behavioural arrest [4] is present in TMEV mice but not in PBS mice [1]. Activity observed during a generalised convulsive seizure is expanded for comparison [2]. Figures were compiled from Stewart et al. [98]. b, c Hippocampal changes in a TMEV-infected mouse with acute seizures. b H\&E-stained half-coronal sections show normal cytoarchitecture in a mock-infected control mouse and hippocampal lesions in a TMEV-infected mouse at 7 days p.i.. Higher magnification of the hippocampal layer (c) shows severe loss of pyramidal cells in the CA1 sector (arrows), while the dentate gyrus (DG) seems to be relatively intact. Note also the inflammatory lympho-histiocytic predominantly perivascular cells in the hippocampus in c (arrowheads). Scale bar (b) $1 \mathrm{~mm}$; (c, d) $0.2 \mathrm{~mm}$. Photomicrographs were prepared from brain sections of C57BL/6 mice infected with the DA strain of TMEV in a study (Bröer et al. [22]), which reproduced the initial findings of the group led by Fujinami and White [126]

mice deficient in complement component $\mathrm{C} 3$ develop acute seizures following TMEV infection than control wild-type mice [70]. Data suggest that C3 in the CNS is important for the development of seizures [5, 148].

To examine the role of cytokines in the development of acute seizures, the role of interleukin (IL)-1, tumour necrosis factor (TNF)- $\alpha$ and IL- 6 which are produced early following virus infection were tested. These cytokines have been detected in sera from people with TLE $[12,131]$ and from resected brain tissue from people with intractable epilepsy $[48,49,111,112]$. Initial testing included different C57BL/6 mice that were deficient in these cytokines or their receptors, and mice were followed for the development of seizures. Surprisingly, mice deficient in IL-1R1 and MyD88 (IL-1 signals through MyD88) developed seizures following TMEV infection similar to control wildtype mice [66]. Conversely, fewer mice deficient in TNFR1 and IL- 6 developed seizures than wild-type mice. When monitoring for TNF- $\alpha$ and IL- $1 \alpha / \beta$ mRNA by PCR at day 6 p.i. (peak of seizures), marked elevations in these mRNAs were found in wild-type mice having seizures compared with wild-type mice without seizures or mice injected with phosphate-buffered saline. TNF- $\alpha$ and IL- 6 contribute to the development of acute seizures in this model. Over 20 years ago, transgenic mice overexpressing IL-6 driven by the glial fibrillary acidic protein (GFAP) promoter were found to develop spontaneous seizures [27]. There is also evidence that TNF-R1 mediates the proconvulsive effects of TNF- $\alpha$ in mice exposed to chemoconvulsants $[9,10$, 144].

The extent of infiltrating monocytes/macrophages and activated microglial cells, as well as reactive astrocytes, was monitored in the TMEV model [126]. There was a marked infiltration of monocytes/macrophages and enhanced numbers of activated microglia as detected by Ricinus communis agglutinin (RCA)-I lectin histochemistry of brain sections from mice with seizures. RCA-1 staining, as well as increased GFAP staining (reactive astrocytes), was noted up to at least day 35 p.i. in mice with acute seizures. A subset of these mice went on to develop spontaneous recurrent seizures (Fig. 11a) [126]. To assess the role of the infiltrating cells and IL-6, polymorphonuclear leukocytes (PMNs), monocytes/macrophages or NK cells were depleted using depleting antibodies [71] or clodronate (unpublished). Depletion of PMNs and NK cells did not alter numbers of infected mice developing seizures, but depletion of macrophages did. Compounds such as minocycline that modulate the activation and inflammatory phenotype of monocyte/macrophages and microglial cells also reduced the numbers of mice developing seizures [34, 71].

Early data suggested that TNF- $\alpha$ and IL- 6 were important in the development of acute seizures. To determine which cells were producing these cytokines, macrophages and microglia were isolated and intracellular cytokine staining using flow cytometry was used. These cells were isolated at day 3 p.i. and cytokine levels between resident microglia and infiltrating macrophages were compared. Higher numbers of microglia than macrophages were positive for TNF- $\alpha$. In contrast higher numbers of macrophages were positive for IL-6. In other studies, mice were treated 
with minocycline or wogonin and numbers of microglia versus macrophages were determined. Both wogonin and minocycline reduced the numbers of infiltrating macrophages into the CNS by twofold [34]. These data are consistent with mononuclear cell infiltration in mesial TLE. Higher numbers of $\mathrm{CD} 45^{+}$cells were observed in the hippocampal tissue of people with mesial TLE compared with control non-mesial TLE tissue sections [74, 149]. High numbers of macrophages $\left(\mathrm{CD} 45^{\mathrm{hi}} \mathrm{CD} 11 \mathrm{~b}^{+}\right.$cells) were observed infiltrating into the CNS at day 3 p.i. following TMEV infection. Preliminary data suggest that the adoptive transfer of bone marrow-derived monocytes into TMEVinfected mice increases the number of mice developing seizures. These observations demonstrate the importance of monocytes/macrophages and microglial cells in the development of seizures; it is likely, however, that a combination of multiple contributing factors, including reactive astrocytes, ultimately results in seizures [55].

In addition to being an important platform for studying the mechanisms underlying viral-induced epilepsy, the TMEV mouse is an important etiologically relevant model for assessing the impact of acute interventions on epileptogenesis and the comorbidities associated with epilepsy [11]. For example, TMEV-infected C57BL/6 mice treated twice daily with valproic acid (VPA; $200 \mathrm{mg} / \mathrm{kg}$ ) during the acute infection period (days $0-7$ p.i.) displayed a lower overall seizure burden than mice treated with either carbamazepine (CBZ; $20 \mathrm{mg} / \mathrm{kg}$, twice daily) or vehicle (twice daily). More CBZ-treated mice presented with acute seizures. VPA-treated mice also showed improved motor performance 15 days p.i. CBZ-treated mice, but not VPAtreated mice, displayed an anxiety-like profile in the open field test when tested at 36 days p.i. [11]. Ongoing investigations are aimed at further characterisation of these observations and the characterisation of other acute interventions on the acute and long-term changes associated with TMEVinduced encephalomyelitis. Importantly, while all of the above-described experiments in the TMEV model of infection-induced epilepsy arose from a cooperation between the groups of Robert Fujinami and Steve White (University of Utah), the model was recently successfully reproduced by a group of researchers in Hannover, Germany, and is was found that the seizure/epilepsy phenotype depended on the TMEV strain/substrain and C57BL/6 mouse substrain used [22].

An interesting example of an experimental model of infection-induced acute seizures has recently been reported by Buckingham et al. [25], using a well-established mouse model of cerebral malaria [37]. Buckingham et al. [25] were the first to use continuous EEG and video monitoring of seizures after infection with Plasmodium berghei in this mouse model. However, as with most models of infectioninduced seizures, only early seizures could be recorded following infection, because mice died or became moribund within 1-2 weeks. Interestingly, Buckingham et al. [25] found that complement C5-deficient mice are protected from seizures in this model. The data suggest a role for the membrane attack complex (MAC) of complement in malaria-induced seizures and that inhibition of the terminal complement pathway may reduce seizures and seizurerelated neurocognitive deficits.

\section{The sterile (non-infectious) inflammatory response that occurs following brain insults and its potential role in epileptogenesis}

\section{Definition and key molecules of sterile inflammation}

Sterile inflammation is a homeostatic tissue response to injury triggered by endogenous molecules called danger signals (DS) or alarmins. Virtually every cell type can release these molecules when the tissue is exposed to biological stressors, to alert the environment of imminent or ongoing damage, and consequently to activate homeostatic programmes for tissue repair and healing. DS activate the so-called pattern recognition receptors (PRR), namely tolllike receptors (TLR) and nucleotide-binding oligomerization domain receptors (NOD)-like receptors that are typically expressed by innate immunity cells, and recognise damage-associated molecular pattern (DAMP) motifs expressed by danger signals. Notably, PRR also recognise pathogens during infection (pathogen-associated molecular patterns, PAMPs), and this dual recognition role identifies PRR as a key nodal regulator of homeostatic tissue responses to damage or infection. Activation of PRR both by DS or pathogens results in the transcriptional activation of NFkB-sensitive inflammatory genes, thereby leading to the generation and rapid amplification of the inflammatory cascade that is instrumental for the recognition and removal of the injurious agent and for promoting tissue healing and repair. As with every homeostatic response, however, if the activation of PRR is protracted and not strictly controlled by endogenous anti-inflammatory mechanisms, it may lead to tissue damage or dysfunction [137].

\section{Sterile inflammation in the CNS}

In the normal brain, PRR are expressed at barely detectable levels in neurons, glia and endothelial cells of microvessels, but they are rapidly induced in these cells following an epileptogenic insult (e.g. status epilepticus, stroke, neurotrauma, CNS infection, etc.) to experimental animals, as well as during recurrent seizures. Concomitantly, there is evidence of a rapid release of DS, such as ATP, high mobility group box 1 (HMGB1), heat shock proteins (HSP), 
S100ß, formyl peptides, mitochondrial DNA from injured neurons and activated microglia and astrocytes, as well as the production of break-down products of the extracellular matrix, such as hyaluronates, that activate PRR [16, 137]. Similarly to experimental models, upregulation of both PRR and DS has been demonstrated in human epileptogenic foci surgically resected in various (structural/ lesional) forms of pharmacoresistant epilepsy [59, 86, 151]. This evidence supports the suggestion that PRR are activated by DS in epilepsy in the absence of infections, and raises the crucial question of the pathophysiological role of this phenomenon. Pharmacological studies in experimental models have been instrumental in demonstrating that sterile inflammation may have profound effects on seizures and possibly plays a role in epileptogenesis [137].

\section{Induction of sterile inflammation and its role in epileptogenesis}

Immunohistochemical and biochemical analyses of DS/ DAMPs and PRR in experimental models of epilepsy showed that these mediators of sterile inflammation, and the associated effector inflammatory molecules (IL-1 $\alpha$, TNF- $\alpha$, IL- 6 , prostaglandins, etc.) are induced in neurons and glia, as well as in the endothelium of the BBB, following non-infectious epileptogenic events and before epilepsy onset. This phenomenon has a rapid onset (within min to hours), persists after the inciting event has elapsed (days to weeks), and is still detectable in chronic epilepsy tissue characterised by spontaneous recurrent seizures [139, 140]. The persistence of these inflammatory events suggests that the endogenous mechanisms that should be activated to promote rapid resolution, thus preserving the homeostatic response, are instead inefficient. Anti-inflammatory molecules such as IL-1 receptor antagonist (IL-1Ra) that controls IL-1 $\beta$ signalling and CD59 that controls complement activation, and the transcriptional factor ATF3 that controls TLR4 expression, are induced only moderately compared with their proinflammatory counterpart $[5,36,45,46,104]$. The inflammatory molecules that persist in brain tissue may become detrimental for brain function and cell survival, as demonstrated in experimental models.

To understand the role of inflammation in acute seizure generation mechanisms and in epileptogenesis, two main approaches have been developed. In the first approach, seizure susceptibility and epileptogenesis were assessed in transgenic mice with deletion or amplification of specific neuroinflammatory signallings. Conversely, molecules and drugs mimicking or blocking PRR activation by DS were intracerebrally or systemically applied to animals either before provoking acute seizures or during recurrent spontaneous seizures in established chronic epilepsy, or after epileptogenic events and before the onset of the disease. The resulting data show that PRR activation by DS, and specific effector members of the inflammatory cascade, contribute to the mechanisms of seizure generation and recurrence, and may also be implicated in the development of the disease [87, 88, 137]. In particular, genetic ablation or pharmacological antagonism of TLR3 (Gross et al., personal communication), and TLR4 $[59,86]$ or IL-1R type 1 [87, $135,136]$ drastically reduced acutely evoked or chronic recurrent seizures in animal models, and ameliorated the disease outcomes when applied before the onset of epilepsy $[68,100]$. Reduction of cell loss and reduction of comorbidities were also beneficial effects observed when COX-2 and prostaglandin E2 were antagonised during epileptogenesis [116].

\section{How should we explain the development of early and late seizures after brain infections and sterile inflammation?}

The mechanisms of the generation of acute symptomatic seizures after infections vary with the type of infection and are often multifactorial [124]. The triggering of the inflammatory cascade with release of inflammatory cytokines appears to be a common underlying factor in most CNS infections and has been well studied in meningitis and encephalitis [124]. As described below for sterile inflammation, prolonged stimulation of proinflammatory signals either by chronic inflammation or by seizures themselves may lead to a residual pathological state such as damaged $\mathrm{BBB}$, neuronal death, and persistent neuronal hyperexcitability-all of which may contribute to epileptogenesis. In general, however, the mechanisms of epilepsy following CNS infections are not well established, although data from experimental models, as exemplified by the TEMV model described above, may advance our knowledge about the mechanisms of acute and late seizures following brain infection. In individuals with brain infections, structural damage such as cortical necrosis with herpes simplex virus, infarction in meningitis, hypoxic-ischaemic injury in cerebral malaria, and gliosis around calcified NCC may all constitute epileptogenic foci [124]. Hyperthermia associated with various CNS infections can also itself lead to neuronal hyperexcitability [77] as discussed below.

\section{Mechanisms mediating the pathological consequences of sterile inflammation}

The induction of inflammatory mediators in seizure-prone brain areas is induced by cell injury, seizures, or their combination. The presence of degenerating neurons amplifies the inflammatory response, but cell death is not instrumental in the induction of sterile inflammation in the brain. 
The release of DS and cytokines, such as HMGB1 and IL- $1 \beta$, is highly dependent on intracellular ionic changes that are associated with tissue hyperexcitability (i.e. $\mathrm{K}^{+}$ and $\mathrm{Cl}^{-}$efflux, $\mathrm{Na}^{+}$influx) and, moreover, the intracellular signalling that these molecules activate chiefly depends on the target cells (Fig. 3). For example, the activation of IL-1R1 and TLR4 expressed by microglia and astrocytes by their endogenous ligands mediates NFkB- and activator protein 1 (AP-1)-dependent inflammatory gene transcription, thereby perpetuating inflammatory events that involve the release of cytokines and chemokines, the induction of COX-2 and the complement system, and may subsequently lead to the brain recruitment of leukocytes. The same receptors activated in endothelial cells of the BBB contribute to its increased permeability to serum macromolecules, such as $\operatorname{IgG}$ and albumin, by promoting the break-down of tight junctions [92], and may favour leukocytes brain extravasation by inducing adhesion molecules on microvessels. The extravasation of serum protein may, in turn, induce astrocytic dysfunctions that contribute to hyperexcitability by impairing their ability to buffer extracellular $\mathrm{K}^{+}$and water, and induce transcription of inflammatory genes in astrocytes via activation of the transforming growth factor (TGF)- $\alpha$ signalling $[58,139]$. PRR and IL-1R1 activation in neurons may rapidly increase neuronal excitability via post-translational modification of receptor-gated or voltagedependent ion channels, mostly mediated by activation of protein kinase $\mathrm{C}$ (PKC) and proto-oncogene, nonreceptor tyrosine kinase (Src) family of protein kinases [137, 141]. Not least, although still unexplored, is the epigenetic effect mediated by DS such as HMGB1. This molecule is physiologically bound to nuclei in every cell type but can rapidly be translocated following brain injury and during seizures to the cytoplasm from where it is extracellularly released. Chromatin-bound HMGB1 regulates gene transcription, and recent evidence in macrophages and fibroblasts showed that, on its nuclear-to-cytoplasmatic translocation, the cell phenotype is significantly altered (Marco Bianchi, personal communication). If the same effects are induced in brain cells, HMGB1 translocation during epileptogenesis may lead to epigenetic changes in neurons and glia with a possible impact on cell function and disease outcomes [67].

\section{Long-term consequences of systemic and CNS inflammation on immature brain function, and their role in experimental febrile seizures}

Febrile seizures in experimental models trigger sterile inflammation: both DS and cytokines are rapidly induced in immature rat and mouse forebrain following febrile-like seizures induced by increased core temperature to mimic fever $[30,42,51]$. The brain increase in inflammatory molecules mainly occurs in microglia $[51,114]$ and astrocytes [42], and there is recent evidence of HMGB1 translocation in neurons [29]. The data prove that is the seizure activity per se, and not the increment in core or brain temperature, that provokes neuroinflammation. The induction of febrile seizures by hyperthermia in animal models requires the activation of IL- $1 \beta / \mathrm{IL}-1 \mathrm{R} 1$ axis since mice lacking IL-1R1 display an increased temperature threshold for seizure induction, and treatment with intracerebroventricular IL-1 $\beta$ before hyperthermia lowers seizure threshold [41]. Notably, about $30 \%$ of immature rats exposed to hyperthermia-induced seizures develop epilepsy and these animals show persistent neuroinflammation which is lacking in rats similarly exposed to febrile-like seizures but not developing epilepsy [42]. These data show that sterile inflammation determines the threshold for the occurrence of experimental febrile seizures, and possibly also contributes to the progression of disease.

Febrile seizures in children often, but not always, occur in the context of an ongoing systemic infection. This clinical setting has been reproduced in immature rodents by systemic administration of lipopolysaccharide (LPS) to mimic Gram-negative infections or Poly I:C to mimic viral infections, and the associated fever. This acute challenge imposed in a specific developmental window (PN7PN14) promotes convulsions in immature rats exposed to doses of kainic acid that are ineffective in naive animals, thus showing that seizure threshold is decreased $[51,114]$. The increased susceptibility to provoked seizures was maintained in the animals until their adulthood. Systemic inflammation, not the fever per se, transiently induced IL- $1 \alpha$ and TNF- $\alpha$ in the hippocampus and neocortex, and prevention of this brain response with minocycline, an inhibitor of microglia activation, or using IL-1Ra or TNF- $\alpha$ inactivating antibodies, precluded both the acute and longterm reduction in seizure threshold, as well as the comorbidities (anxiety-like behaviour and learning and memory deficits) observed in adulthood [51, 114]. This transient inflammatory challenge permanently altered the expression of glutamate receptor subtypes and the $\mathrm{K}^{+} / \mathrm{Cl}^{-}$co-transporter in rat forebrain, which may have implications for the observed long-term pathophysiological outcomes [113, 115]. Pre-exposure of immature rodents to LPS before inducing status epilepticus enhances cell loss in forebrain [6], and LPS alone increases the severity of epilepsy when the animal is exposed to status epilepticus in adulthood [7].

\section{Antibody-mediated encephalitis and epilepsy}

Traditionally, the vast majority of encephalitides have been ascribed a microbiological aetiology. However, more recently it has been recognised that many are due to 
Table 3 Spectrum of antibody-associated epileptic encephalitides

\begin{tabular}{|c|c|c|c|}
\hline Antibody-target & Epitopes & Clinics & Neuropathology \\
\hline Intracellular & GAD65, AMP & VAR. (NPE) & $\begin{array}{l}\text { CD8-positive T-cells and neuronal cell loss preferentially in } \\
\text { hippocampus }\end{array}$ \\
\hline Intranuclear & $\mathrm{Hu}, \mathrm{Yo}, \mathrm{Ma} 2$ & $\mathrm{PE}$ & CD8-positive T-cells attacking neurons \\
\hline Voltage-gated potassium channel complex (VGKC) & $\begin{array}{l}\text { LGI1 } \\
\text { Caspr2 }\end{array}$ & NPE (PE) & $\begin{array}{l}\text { CD8-positive T-cells attacking neurons, severe cell loss } \\
\text { preferentially in hippocampus }\end{array}$ \\
\hline Glutamate receptors & NMDA R1 & NPE (PE) & Few T-cells, only mild neuronal cell loss \\
\hline
\end{tabular}

Most of these antibody-associated encephalitides can occur with or without an underlying neoplasm

$G A D$ glutamic acid decarboxylase, AMP amphiphysin, VAR variable, NPE non-paraneoplastic encephalitis, $P E$ paraneoplastic encephalitis, LGI1 leucine-rich glia-inactivated 1, Caspr2 contactin-associated protein-like 2, NMDA N-methyl-D-aspartate

immunological, often autoimmune, mechanisms. Antibodymediated limbic encephalitis is an increasingly recognised cause of seizures in acquired epilepsy, most commonly localised to the temporal lobe [32]. Acute inflammation of the mesial temporal regions during limbic encephalitis can lead to hippocampal atrophy consistent with mesial temporal sclerosis on magnetic resonance imaging [32].

Antibody-associated encephalitis is either classified as paraneoplastic (PE) or non-paraneoplastic limbic encephalitis [13, 17]. Paraneoplastic neurological disorders can harm any part of the CNS, such as brainstem, the limbic system or just single cell types, i.e. Purkinje cells in paraneoplastic cerebellar degeneration. Although multiple areas of the CNS can be involved, PE most often affects the limbic system and termed already in 1968 as limbic encephalitis by Corsellis [33]. Antibodies can react with both, the nervous system and the underlying cancer, but some evidence suggests a correlation between neurological deficits and antibody targets rather than with an underlying specific tumour [13]. These studies have supported the concept of non-paraneoplastic antibody-mediated encephalitis (NPE), in which encephalitic patients present with similar neurological deficits, including epilepsy, but extensive diagnostic tests and follow-up failed to detect cancer.

Nowadays, antibody-mediated encephalitis can be classified according to serum antibodies and their specific targets (see Table 3): (1) antibodies directed against intracellular antigens (such as GAD65); (2) intranuclear antigens (such as $\mathrm{Hu}$, Yo and Ma2) as prototypic onco-neural antigens; (3) antibodies directed against neuronal membrane antigens such as the VGKC (voltage-gated potassium channel) complex, various glutamate receptors (NMDA or AMPA receptors or metabotropic glutamate receptor subunits) or the $\mathrm{GABA}_{\mathrm{B}}$ receptor.

Detection of these antibodies is clinically relevant and should be confirmed in specialised laboratories using a patient's serum. However, their pathogenic role is still matter of ongoing investigations. Generally, it is assumed that antibodies against intracellular antigens are less or not pathogenic [56] as antibodies will hardly reach intracellularly located neural antigens in normal brain. Exceptions may be antibodies to GAD65 [82] or to amphiphysin [54]. In neuropathological studies of PE with anti-Hu, anti-Yo, or anti-Ma antibodies, CD8-positive T-cells dominate inflammatory infiltrates [110], which possess cytotoxic granules and are in close apposition to neurons suggesting that cytotoxic T-lymphocytes play a role in neuronal cell death.

\section{Voltage-gated potassium channel (VGKC) complex encephalitis}

Antibodies against VGKC complex were detected first in PE [26] but more patients present with non-paraneoplastic ("idiopathic") limbic encephalitis [107]. Antibodies are directed to potassium channel complex proteins, such as contactin-associated protein-like 2 (Caspr2) and leucinerich, glioma-inactivated 1 (LGI1) [110]. Antibodies against LGI1 are more often found than antibodies against Caspr2 [60]. Clinically, these patients present with memory loss, confusion, behavioural changes and seizures [110]. In addition, patients with LGi1 antibodies present with facio-brachial dystonic seizures preceding limbic encephalitis [62]. Histopathologically, surgical specimens obtained from patients with anti-VGKC complex reveal neuronal cell loss in the presence of infiltrating T-cells and perivascular B-cells [110]. Patients with antibodies specific for LGI1 or caspr 2 show inflammation and severe degeneration in the hippocampus. Importantly, antibody lowering treatments like plasma exchange have been found to improve neurological deficits in these patients, suggesting that antibodies directed against the VGKC complex are responsible for clinical symptoms (Ramanathan et al. [110]).

\section{NMDA receptor-associated encephalitis}

Histopathology findings in patients with antibodies directed against the NMDAR, a subtype of glutamate 
receptors in the brain, differ from most other antibodyassociated encephalitidides. Although the disease is defined as "encephalitis", brain parenchyma of PE patients reveals relatively few inflammatory cells, and T-cells, B-cells and plasma cells remain in the perivascular space of blood vessels [91]. It is important to note that neuronal loss is remarkably mild in these patients. In some reports, this syndrome therefore is referred to as "encephalopathy" rather than encephalitis, thereby underlining the functional character of damage in contrast to only mild structural signatures in this disease [61].

The clinical presentation of patients with NMDARassociated encephalitis (also termed anti-NMDAR autoimmune encephalitis) is remarkable. It occurs mainly in young females with a peak of age at onset between 19 and 24 years [91, 110]. Clinically, a prodromal stage with symptoms such as fever, nausea, vomiting or diarrhoea may be found in retrospect. After few weeks, patients develop seizures, (partial) status epilepticus, short-term memory loss and, in addition, psychiatric symptoms such as anxiety, insomnia, fear, mania and paranoia. This phase is followed by the initiation of abnormal movements of limb and trunk and oro-lingual-facial dyskinesias, a sudden spontaneous fall in consciousness and autonomic manifestations such as tachy- or bradycardia, hyperventilation and central hypoventilation $[91,110]$. At this stage, patients need to be managed in intensive care units. However, most patients completely recover, and follow-up MRI studies do not detect permanent brain atrophy $[91,110]$.

The clinical syndrome of NMDAR encephalitis was first reported in 2005 in patients with paraneoplastic encephalitis resulting from ovarian teratomas harbouring antibodies to hippocampal neuropil [1]. Soon after, it was discovered that this particular syndrome was associated with antibodies against the NR1 subunit of the NMDAR [35]. Anti-NMDAR encephalitis was also found in the absence of a tumour in a large number of patients [91, 110]. AntiNMDAR antibodies do not activate complement, but decrease the NMDA receptor density by cross-linking and subsequent internalisation, leading to a state of reversible NMDAR hypofunction [91, 110]. Further studies with CSF from patients with anti-NMDAR antibody encephalitis suppressed induction of long-term potentiation (LTP) in mouse hippocampal slices [150], suggesting that these antibodies can act as an NMDAR antagonist and thus may be involved in amnesia. However, there is yet no evidence for complement-mediated or cytotoxic T-cell-mediated neuronal cell death in this disease.

\section{Glutamate decarboxylase 65 (GAD65) encephalitis}

Glutamate decarboxylase (GAD) is the principal, ratelimiting enzyme that catalyses the synthesis of the neurotransmitter GABA and occurs in two isoforms, GAD65 and GAD67. GAD antibodies are associated with a broad spectrum of diseases, i.e. patients with neurological disorders or diabetes mellitus type 1 [125, 127]. Neurological diseases are associated with very high GAD antibody concentrations being two to three log ranks higher than in the diabetic population [110]. The spectrum of neurological conditions associated with GAD antibodies ranges is broad [117], including stiff-man syndrome, cerebellar ataxia, limbic encephalitis and pharmacoresistant TLE, which is probably the chronic form of GAD antibody-associated limbic encephalitis. Some experimental conditions have provided evidence that these antibodies might contribute to a loss of GABAergic inhibition [81, 82]. Histopathological studies have shown neuronal loss and axonal dystrophy in the hippocampi of these patients, whereas Ig and complement deposition were absent from these brains. Since the antigen is intracellular, a T-cell-mediated pathology would be a likely mechanism.

\section{Autoantibodies targeting other receptor or channel complexes}

Autoimmune encephalitis is a rapidly growing field and new antibodies targeting receptor or channel complexes are increasingly identified. Discussion of all these antibodies is beyond the scope of this review. Examples for recently identified antibodies that cause encephalitis and epilepsy include antibodies against AMPA receptors (another subtype of glutamate receptors), $\mathrm{GABA}_{\mathrm{B}}$ receptors, dopamineD2 receptors and glycine receptors [120]. Whether Rasmussen's encephalitis, an inflammatory encephalopathy characterised by progressive refractory partial seizures, cognitive deterioration, and focal deficits that occur with gradual atrophy of one brain hemisphere, also has an autoimmune aetiology is controversially discussed [4]. Understanding the molecular details of autoantibody actions on receptor and channel complexes is highly desirable and may open the path to develop specific therapies to treat humoral autoimmune encephalitis.

With respect to the discussion on autoimmune encephalitis in the context of our review, there is an important caveat. In our review, we aim at showing that infections can promote seizures and epileptogenesis by activating overlapping pathways with classical sterile inflammation, which by definition occurs in association with a brain damage or tissue injury. Autoimmune diseases likely act by different mechanisms in promoting seizures, most of which are largely unknown or still under evaluation, such as autoantibody-mediated inactivation of ion channels and others. It is still unknown and mostly unexplored if autoantibodies would also indirectly activate sterile mechanisms of inflammation in the brain as discussed above. 


\section{Strategies to prevent epilepsy resulting from brain infections and non-infectious inflammation}

In principle, there are at least three strategies to prevent epilepsy after brain infections or other epileptogenic brain insults (Fig. 1), (1) prevention of the initial insult, (2) initial insult modification (diminishing the long-term consequences of the insult by reducing the severity or duration of the initial brain insult), and (3) "true" antiepileptogenesis or disease modification after the insult by interfering with the mechanisms underlying epileptogenesis [79].

Improvements to sanitation, eradication of infectious agents, immunisation/vaccination, or antibiotic prophylaxis would be examples of prevention of the initial insult, i.e. the infection. Appropriate treatment of the CNS infection and correction of predisposing factors such as fluid and electrolyte imbalance would modify the initial insult and thereby may reduce the risk of long-term consequences. Antiepileptogenesis or disease modification after the infection includes treatments that directly target the complex mechanisms underlying epileptogenesis [80].

As discussed above, the available experimental evidence supports the idea that inflammation in brain caused by either sterile injuries or by infections may contribute to acute seizures and epilepsy development using partially overlapping mechanisms, therefore, highlighting putative common target for therapeutic interventions which may not only suppress the symptoms of the disease but also interfere with key pathogenic mechanisms. One can envisage the use of specific anti-inflammatory drugs blocking the key pathogenic inflammatory mechanisms [142]. The advantage of this approach is that some of these drugs are already available in the clinic for the treatment of auto-inflammatory or autoimmune diseases [e.g. IL-1Ra/ anakinra, anti-IL- $\alpha$ (canakinumab) or TNF- $\alpha$ antibodies (infliximab) or receptor fusion proteins (etanercept)] and pre-clinical research has determined the therapeutic potential of new drugs with neuroprotective and diseasemodifying effects (e.g. EP2 receptor antagonists, TLR3 or TLR4 antagonists). The challenge, however, is to design an intervention that blocks the detrimental arm of brain inflammation without interfering with the homeostatic mechanisms; in this context, the implementation of resolving anti-inflammatory mechanisms rather than the prevention of the inflammatory cascade from occurring may be a better strategy. Preventing inflammation may also be difficult due to the rapid onset and amplification of the cascade after the first inciting event. The development of a biomarker of brain inflammation would be of great help to monitor the efficacy of an anti-inflammatory intervention, and determine when the treatment can be stopped [138].

\section{Conclusions}

Several infections, mostly preventable, are associated with seizures and epilepsy. Awareness of these causes, their geographical distribution, and burden could be helpful to clinicians in formulating differential diagnoses and to health providers in prioritising resources towards appropriate preventative/control measures [124]. The exact risks of developing seizures are poorly understood, but appear to relate to the pathogen, the degree of cortical involvement, maturation of the brain, genetic makeup and the cytokine-mediated inflammatory response. This is clearly an area of great clinical importance requiring further investigation. Insight into the mechanisms of seizures and epilepsy in CNS infections could help in evolving innovative antiepileptogenic interventions. In this respect, it is important to note that both infectious and non-infectious causes of inflammation share common molecular pathways and mechanisms that are critically involved in the processes leading to epilepsy (Figs. 1, 2), so that novel anti-inflammatory treatments may be effective strategies for disease modification. In addition, prevention of CNS infections such as meningitis and encephalitis through immunisation and eradication of parasitic infections by increasing public awareness and improving sanitation are the definitive steps towards reducing the burden of epilepsy [124].

Acknowledgments AV and WL have received funding from the European Union's Seventh Framework Programme (FP7/2007-2013) under Grant Agreement No. 602102 (EPITARGET). WL's research is supported by the Niedersachsen-Research Network on Neuroinfectiology (N-RENNT) of the Ministry of Science and Culture of Lower Saxony (Germany) and AV's research by the Fondazione Monzino. RSF is supported by NIH R01 NS065714. JWS is based at the UCLH/UCL Comprehensive Bio-Medical Research Centre which received a proportion of funding from the Department of Health's NIHR Biomedical Research Centres funding scheme. JWS receives research support from the Dr. Marvin Weil Epilepsy Research Fund and the UK Epilepsy Society. IB received funding from the European Union's Seventh Framework Program under Grant Agreement No. 602531 (DESIRE). We thank Dr. Ingo Gerhauser, Christopher Käufer and Dr. Sonja Bröer for preparing the photomicrographs in Fig. 11, Drs. Arturo Carpio Rodas, Indran Davagnanam and Chandrashekar Hoskote for providing brain images of patients, and Profs. Wolfgang Brück, Roland Nau and Thomas Henze for providing brain sections or photomicrographs of patients. We are grateful to Dr. Gail S Bell for critically reviewing the manuscript.

\section{References}

1. Ances BM, Vitaliani R, Taylor RA, Liebeskind DS, Voloschin A, Houghton DJ, Galetta SL, Dichter M, Alavi A, Rosenfeld MR, Dalmau J (2005) Treatment-responsive limbic encephalitis identified by neuropil antibodies: MRI and PET correlates. Brain 128:1764-1777

2. Annegers JF, Hauser WA, Beghi E, Nicolosi A, Kurland LT (1988) The risk of unprovoked seizures after encephalitis and meningitis. Neurology 38:1407-1410 
3. Annegers JF, Rocca WA, Hauser WA (1996) Causes of epilepsy: contributions of the Rochester epidemiology project. Mayo Clin Proc 71:570-575

4. Armangue T, Petit-Pedrol M, Dalmau J (2012) Autoimmune encephalitis in children. J Child Neurol 27:1460-1469

5. Aronica E, Boer K, van Vliet EA, Redeker S, Baayen JC, Spliet WG, van Rijen PC, Troost D, da Silva FH, Wadman WJ, Gorter JA (2007) Complement activation in experimental and human temporal lobe epilepsy. Neurobiol Dis 26:497-511

6. Auvin S, Shin D, Mazarati A, Nakagawa J, Miyamoto J, Sankar $\mathrm{R}$ (2007) Inflammation exacerbates seizure-induced injury in the immature brain. Epilepsia 48(Suppl 5):27-34

7. Auvin S, Mazarati A, Shin D, Sankar R (2010) Inflammation enhances epileptogenesis in the developing rat brain. Neurobiol Dis 40:303-310

8. Bale JF Jr (2015) Virus and immune-mediated encephalitides: epidemiology, diagnosis, treatment, and prevention. Pediatr Neurol 53:3-12

9. Balosso S, Ravizza T, Perego C, Peschon J, Campbell IL, De Simoni MG, Vezzani A (2005) Tumor necrosis factoralpha inhibits seizures in mice via p75 receptors. Ann Neurol 57:804-812

10. Balosso S, Ravizza T, Aronica E, Vezzani A (2013) The dual role of TNF-alpha and its receptors in seizures. Exp Neurol 247:267-271

11. Barker-Haliski ML, Dahle EJ, Heck TD, Pruess TH, Vanegas F, Wilcox KS, White HS (2015) Evaluating an etiologically relevant platform for therapy development for temporal lobe epilepsy: effects of carbamazepine and valproic acid on acute seizures and chronic behavioral comorbidities in the Theiler's murine encephalomyelitis virus mouse model. J Pharmacol Exp Ther 353:318-329

12. Bauer J, Vezzani A, Bien CG (2012) Epileptic encephalitis: the role of the innate and adaptive immune system. Brain Pathol 22:412-421

13. Bauer S, Cepok S, Todorova-Rudolph A, Nowak M, Koller M, Lorenz R, Oertel WH, Rosenow F, Hemmer B, Hamer HM (2009) Etiology and site of temporal lobe epilepsy influence postictal cytokine release. Epilepsy Res 86:82-88

14. Beghi E, Carpio A, Forsgren L, Hesdorffer DC, Malmgren K, Sander JW, Tomson T, Hauser WA (2010) Recommendation for a definition of acute symptomatic seizure. Epilepsia 51:671-675

15. Berg AT, Berkovic SF, Brodie MJ, Buchhalter J, Cross JH, van Emde BW, Engel J, French J, Glauser TA, Mathern GW, Moshe SL, Nordli D, Plouin P, Scheffer IE (2010) Revised terminology and concepts for organization of seizures and epilepsies: report of the ILAE Commission on Classification and Terminology, 2005-2009. Epilepsia 51:676-685

16. Bianchi ME (2007) DAMPs, PAMPs and alarmins: all we need to know about danger. J Leukoc Biol 81:1-5

17. Bien CG, Elger CE (2007) Limbic encephalitis: a cause of temporal lobe epilepsy with onset in adult life. Epilepsy Behav 10:529-538

18. Birbeck GL, Molyneux ME, Kaplan PW, Seydel KB, Chimalizeni YF, Kawaza K, Taylor TE (2010) Blantyre Malaria Project Epilepsy Study (BMPES) of neurological outcomes in retinopathy-positive paediatric cerebral malaria survivors: a prospective cohort study. Lancet Neurol 9:1173-1181

19. Bittencourt PR, Sander JW and Mazer S (1999) Viral, bacterial, fungal and parasitic infections associated with seizure disorders. In: Meinardi H (ed) Handbook of clinical neurology, The epilepsies, vol 72. Elsevier, Amsterdam, pp 145-174

20. Blümcke I, Thom M, Aronica E, Armstrong DD, Bartolomei F, Bernasconi A, Bernasconi N, Bien CG, Cendes F, Coras R, Cross JH, Jacques TS, Kahane P, Mathern GW, Miyata H, Moshe SL, Oz B, Ozkara C, Perucca E, Sisodiya S, Wiebe S,
Spreafico R (2013) International consensus classification of hippocampal sclerosis in temporal lobe epilepsy: a Task Force report from the ILAE Commission on Diagnostic Methods. Epilepsia 54:1315-1329

21. Brouwer MC, Tunkel AR, McKhann GM, van de Beek D (2014) Brain abscess. N Engl J Med 371:447-456

22. Bröer S, Haist V, Gerhauser I, Bankstahl M, Ulrich R, Brandt C, Löscher W, Baumgärtner W (2014) Viral encephalitis-induced epilepsy: pathogenetic studies with the BeAn strain of Theiler's murine encephalomyelitis virus (TMEV). In: First N-RENNT Symposium on Neuroinfectiology, March 31-April 1, 2014, Hannover (Abstract)

23. Bruner DI, Littlejohn L, Pritchard A (2012) Subdural empyema presenting with seizure, confusion, and focal weakness. West $\mathbf{J}$ Emerg Med 13:509-511

24. Bruno E, Bartoloni A, Zammarchi L, Strohmeyer M, Bartalesi F, Bustos JA, Santivanez S, Garcia HH, Nicoletti A (2013) Epilepsy and neurocysticercosis in Latin America: a systematic review and meta-analysis. PLoS Negl Trop Dis 7:e2480

25. Buckingham SC, Ramos TN, Barnum SR (2014) Complement C5-deficient mice are protected from seizures in experimental cerebral malaria. Epilepsia 55:e139-e142

26. Buckley C, Oger J, Clover L, Tuzun E, Carpenter K, Jackson M, Vincent A (2001) Potassium channel antibodies in two patients with reversible limbic encephalitis. Ann Neurol 50:73-78

27. Campbell IL, Abraham CR, Masliah E, Kemper P, Inglis JD, Oldstone MB, Mucke L (1993) Neurologic disease induced in transgenic mice by cerebral overexpression of interleukin 6 . Proc Natl Acad Sci 90:10061-10065

28. Cendes F, Sakamoto AC, Spreafico R, Bingaman W, Becker AJ (2014) Epilepsies associated with hippocampal sclerosis. Acta Neuropathol 128:21-37

29. Choy M, Dube CM, Patterson K, Barnes SR, Maras P, Blood AB, Hasso AN, Obenaus A, Baram TZ (2014) A novel, noninvasive, predictive epilepsy biomarker with clinical potential. J Neurosci 34:8672-8684

30. Choy M, Dube CM, Ehrengruber M, Baram TZ (2014) Inflammatory processes, febrile seizures, and subsequent epileptogenesis. Epilepsy Curr 14:15-22

31. Colebunders R, Post R, O’Neill S, Haesaert G, Opar B, Lakwo T, Laudisoit A, Hendy A (2015) Nodding syndrome since 2012: recent progress, challenges and recommendations for future research. Trop Med Int Health 20:194-200

32. Correll CM (2013) Antibodies in epilepsy. Curr Neurol Neurosci Rep 13:348

33. Corsellis JA, Goldberg GJ, Norton AR (1968) "Limbic encephalitis" and its association with carcinoma. Brain 91:481-496

34. Cusick MF, Libbey JE, Patel DC, Doty DJ, Fujinami RS (2013) Infiltrating macrophages are key to the development of seizures following virus infection. J Virol 87:1849-1860

35. Dalmau J, Gleichman AJ, Hughes EG, Rossi JE, Peng X, Lai M, Dessain SK, Rosenfeld MR, Balice-Gordon R, Lynch DR (2008) Anti-NMDA-receptor encephalitis: case series and analysis of the effects of antibodies. Lancet Neurol 7:1091-1098

36. De Simoni MG, Perego C, Ravizza T, Moneta D, Conti M, Marchesi F, De Luigi A, Garattini S, Vezzani A (2000) Inflammatory cytokines and related genes are induced in the rat hippocampus by limbic status epilepticus. Eur J Neurosci 12:2623-2633

37. de Souza JB, Hafalla JC, Riley EM, Couper KN (2010) Cerebral malaria: why experimental murine models are required to understand the pathogenesis of disease. Parasitology 137:755-772

38. Del Brutto $\mathrm{OH}$ (2008) Infections and inflammatory diseases. In: Engel JJ, Pedley TA (eds) Epilepsy: a comprehensive textbook, 2nd edn. Lippincott Williams \& Wilkins, Philadelphia, pp 2643-2652 
39. Desena A, Graves D, Warnack W, Greenberg BM (2014) Herpes simplex encephalitis as a potential cause of anti- $N$-methyl-D-aspartate receptor antibody encephalitis: report of 2 cases. JAMA Neurol 71:344-346

40. Donati D, Akhyani N, Fogdell-Hahn A, Cermelli C, CassianiIngoni R, Vortmeyer A, Heiss JD, Cogen P, Gaillard WD, Sato S, Theodore WH, Jacobson S (2003) Detection of human herpesvirus-6 in mesial temporal lobe epilepsy surgical brain resections. Neurology 61:1405-1411

41. Dube C, Vezzani A, Behrens M, Bartfai T, Baram TZ (2005) Interleukin-1beta contributes to the generation of experimental febrile seizures. Ann Neurol 57:152-155

42. Dube CM, Ravizza T, Hamamura M, Zha Q, Keebaugh A, Fok $\mathrm{K}$, Andres AL, Nalcioglu O, Obenaus A, Vezzani A, Baram TZ (2010) Epileptogenesis provoked by prolonged experimental febrile seizures: mechanisms and biomarkers. J Neurosci 30:7484-7494

43. Elbers JM, Bitnun A, Richardson SE, Ford-Jones EL, Tellier R, Wald RM, Petric M, Kolski H, Heurter H, MacGregor D (2007) A 12-year prospective study of childhood herpes simplex encephalitis: is there a broader spectrum of disease? Pediatrics 119:e399-e407

44. Epstein LG, Shinnar S, Hesdorffer DC, Nordli DR, Hamidullah A, Benn EK, Pellock JM, Frank LM, Lewis DV, Moshe SL, Shinnar RC, Sun S (2012) Human herpesvirus 6 and 7 in febrile status epilepticus: the FEBSTAT study. Epilepsia 53:1481-1488

45. Eriksson C, Van Dam AM, Lucassen PJ, Bol JG, Winblad B, Schultzberg M (1999) Immunohistochemical localization of interleukin-1beta, interleukin-1 receptor antagonist and interleukin-1beta converting enzyme/caspase- 1 in the rat brain after peripheral administration of kainic acid. Neuroscience 93:915-930

46. Eriksson C, Tehranian R, Iverfeldt K, Winblad B, Schultzberg M (2000) Increased expression of mRNA encoding interleukin1 beta and caspase-1, and the secreted isoform of interleukin-1 receptor antagonist in the rat brain following systemic kainic acid administration. J Neurosci Res 60:266-279

47. Esposito L, Drexler JF, Braganza O, Doberentz E, Grote A, Widman G, Drosten C, Eis-Hubinger AM, Schoch S, Elger CE, Becker AJ, Niehusmann P (2015) Large-scale analysis of viral nucleic acid spectrum in temporal lobe epilepsy biopsies. Epilepsia 56:234-243

48. Feng ZH, Hao J, Ye L, Dayao C, Yan N, Yan Y, Chu L, Shi FD (2011) Overexpression of mu-calpain in the anterior temporal neocortex of patients with intractable epilepsy correlates with clinicopathological characteristics. Seizure 20:395-401

49. Fiala M, Avagyan H, Merino JJ, Bernas M, Valdivia J, EspinosaJeffrey A, Witte M, Weinand M (2013) Chemotactic and mitogenic stimuli of neuronal apoptosis in patients with medically intractable temporal lobe epilepsy. Pathophysiology 20:59-69

50. Fisher RS, Acevedo C, Arzimanoglou A, Bogacz A, Cross JH, Elger CE, Engel J Jr, Forsgren L, French JA, Glynn M, Hesdorffer DC, Lee BI, Mathern GW, Moshe SL, Perucca E, Scheffer IE, Tomson T, Watanabe M, Wiebe S (2014) ILAE official report: a practical clinical definition of epilepsy. Epilepsia 55:475-482

51. Galic MA, Riazi K, Pittman QJ (2012) Cytokines and brain excitability. Front Neuroendocrinol 33:116-125

52. Garcia HH, Del Brutto OH (2012) Infection and inflammation. Handb Clin Neurol 108:601-620

53. Garcia HH, Nash TE, Del Brutto OH (2014) Clinical symptoms, diagnosis, and treatment of neurocysticercosis. Lancet Neurol 13:1202-1215

54. Geis C, Weishaupt A, Hallermann S, Grunewald B, Wessig C, Wultsch T, Reif A, Byts N, Beck M, Jablonka S, Boettger MK, Uceyler N, Fouquet W, Gerlach M, Meinck HM, Siren AL,
Sigrist SJ, Toyka KV, Heckmann M, Sommer C (2010) Stiff person syndrome-associated autoantibodies to amphiphysin mediate reduced GABAergic inhibition. Brain 133:3166-3180

55. Gibbons MB, Smeal RM, Takahashi DK, Vargas JR, Wilcox KS (2013) Contributions of astrocytes to epileptogenesis following status epilepticus: opportunities for preventive therapy? Neurochem Int 63:660-669

56. Graus F, Saiz A, Lai M, Bruna J, Lopez F, Sabater L, Blanco Y, Rey MJ, Ribalta T, Dalmau J (2008) Neuronal surface antigen antibodies in limbic encephalitis: clinical-immunologic associations. Neurology 71:930-936

57. Gurung P, Lukens JR, Kanneganti TD (2015) Mitochondria: diversity in the regulation of the NLRP3 inflammasome. Trends Mol Med 21:193-201

58. Heinemann U, Kaufer D, Friedman A (2012) Blood-brain barrier dysfunction, TGFbeta signaling, and astrocyte dysfunction in epilepsy. Glia 60:1251-1257

59. Iori V, Maroso M, Rizzi M, Iyer AM, Vertemara R, Carli M, Agresti A, Antonelli A, Bianchi ME, Aronica E, Ravizza T, Vezzani A (2013) Receptor for advanced glycation endproducts is upregulated in temporal lobe epilepsy and contributes to experimental seizures. Neurobiol Dis 58:102-114

60. Irani SR, Alexander S, Waters P, Kleopa KA, Pettingill P, Zuliani L, Peles E, Buckley C, Lang B, Vincent A (2010) Antibodies to Kv1 potassium channel-complex proteins leucinerich, glioma inactivated 1 protein and contactin-associated protein-2 in limbic encephalitis, Morvan's syndrome and acquired neuromyotonia. Brain 133:2734-2748

61. Irani SR, Bera K, Waters P, Zuliani L, Maxwell S, Zandi MS, Friese MA, Galea I, Kullmann DM, Beeson D, Lang B, Bien CG, Vincent A (2010) N-methyl-D-aspartate antibody encephalitis: temporal progression of clinical and paraclinical observations in a predominantly non-paraneoplastic disorder of both sexes. Brain 133:1655-1667

62. Irani SR, Michell AW, Lang B, Pettingill P, Waters P, Johnson MR, Schott JM, Armstrong RJ, Zagami S, Bleasel A, Somerville ER, Smith SM, Vincent A (2011) Faciobrachial dystonic seizures precede Lgil antibody limbic encephalitis. Ann Neurol 69:892-900

63. Kaiser C, Pion SD, Boussinesq M (2013) Case-control studies on the relationship between onchocerciasis and epilepsy: systematic review and meta-analysis. PLoS Negl Trop Dis 7:e2147

64. Kakoti G, Dutta P, Ram DB, Borah J, Mahanta J (2013) Clinical profile and outcome of Japanese encephalitis in children admitted with acute encephalitis syndrome. Biomed Res Int 2013:152656

65. Kamuyu G, Bottomley C, Mageto J, Lowe B, Wilkins PP, Noh JC, Nutman TB, Ngugi AK, Odhiambo R, Wagner RG, Kakooza-Mwesige A, Owusu-Agyei S, Ae-Ngibise K, Masanja H, Osier FH, Odermatt P, Newton CR (2014) Exposure to multiple parasites is associated with the prevalence of active convulsive epilepsy in sub-Saharan Africa. PLoS Negl Trop Dis 8:e2908

66. Kirkman NJ, Libbey JE, Wilcox KS, White HS, Fujinami RS (2010) Innate but not adaptive immune responses contribute to behavioral seizures following viral infection. Epilepsia $51: 454-464$

67. Kobow K, Blumcke I (2014) Epigenetic mechanisms in epilepsy. Prog Brain Res 213:279-316

68. Kwon YS, Pineda E, Auvin S, Shin D, Mazarati A, Sankar R (2013) Neuroprotective and antiepileptogenic effects of combination of anti-inflammatory drugs in the immature brain. J Neuroinflammation 10:30

69. Libbey JE, Kirkman NJ, Smith MC, Tanaka T, Wilcox KS, White HS, Fujinami RS (2008) Seizures following picornavirus infection. Epilepsia 49:1066-1074 
70. Libbey JE, Kirkman NJ, Wilcox KS, White HS, Fujinami RS (2010) Role for complement in the development of seizures following acute viral infection. J Virol 84:6452-6460

71. Libbey JE, Kennett NJ, Wilcox KS, White HS, Fujinami RS (2011) Interleukin-6, produced by resident cells of the central nervous system and infiltrating cells, contributes to the development of seizures following viral infection. J Virol 85:6913-6922

72. Libbey JE, Fujinami RS (2011) Neurotropic viral infections leading to epilepsy: focus on Theiler's murine encephalomyelitis virus. Future Virol 6:1339-1350

73. Linsuwanon P, Puenpa J, Huang SW, Wang YF, Mauleekoonphairoj J, Wang JR, Poovorawan Y (2014) Epidemiology and seroepidemiology of human enterovirus 71 among Thai populations. J Biomed Sci 21:16

74. Loup F, Wieser HG, Yonekawa Y, Aguzzi A, Fritschy JM (2000) Selective alterations in GABAA receptor subtypes in human temporal lobe epilepsy. J Neurosci 20:5401-5419

75. Lowenstein DH (2005) Treatment options for status epilepticus. Curr Opin Pharmacol 5:334-339

76. Lowenstein DH (2009) Epilepsy after head injury: an overview. Epilepsia 50(Suppl 2):4-9

77. Lowenstein DH, Walker M, Waterhouse E (2014) Status epilepticus in the setting of acute encephalitis. Epilepsy Curr $14: 43-49$

78. Löscher W, Gernert M, Heinemann U (2008) Cell and gene therapies in epilepsy-promising avenues or blind alleys? Trends Neurosci 31:62-73

79. Löscher W, Brandt C (2010) Prevention or modification of epileptogenesis after brain insults: experimental approaches and translational research. Pharmacol Rev 62:668-700

80. Löscher W, Klitgaard H, Twyman RE, Schmidt D (2013) New avenues for antiepileptic drug discovery and development. Nat Rev Drug Discov 12:757-776

81. Manto M, Dalmau J, Didelot A, Rogemond V, Honnorat J (2011) Afferent facilitation of corticomotor responses is increased by IgGs of patients with NMDA-receptor antibodies. J Neurol 258:27-33

82. Manto MU, Laute MA, Aguera M, Rogemond V, Pandolfo M, Honnorat J (2007) Effects of anti-glutamic acid decarboxylase antibodies associated with neurological diseases. Ann Neurol 61:544-551

83. Marchi N, Granata T, Janigro D (2014) Inflammatory pathways of seizure disorders. Trends Neurosci 37:55-65

84. Marin B, Boussinesq M, Druet-Cabanac M, Kamgno J, Bouteille B, Preux PM (2006) Onchocerciasis-related epilepsy? Prospects at a time of uncertainty. Trends Parasitol 22:17-20

85. Marks DA, Kim J, Spencer DD, Spencer SS (1992) Characteristics of intractable seizures following meningitis and encephalitis. Neurology 42:1513-1518

86. Maroso M, Balosso S, Ravizza T, Liu J, Aronica E, Iyer AM, Rossetti C, Molteni M, Casalgrandi M, Manfredi AA, Bianchi ME, Vezzani A (2010) Toll-like receptor 4 and high-mobility group box-1 are involved in ictogenesis and can be targeted to reduce seizures. Nat Med 16:413-419

87. Maroso M, Balosso S, Ravizza T, Iori V, Wright CI, French J, Vezzani A (2011) Interleukin-1beta biosynthesis inhibition reduces acute seizures and drug resistant chronic epileptic activity in mice. Neurotherapeutics 8:304-315

88. Maroso M, Balosso S, Ravizza T, Liu J, Bianchi ME, Vezzani A (2011) Interleukin-1 type 1 receptor/toll-like receptor signalling in epilepsy: the importance of IL-1beta and high-mobility group box 1. J Intern Med 270:319-326

89. Michael BD, Solomon T (2012) Seizures and encephalitis: clinical features, management, and potential pathophysiologic mechanisms. Epilepsia 53(Suppl 4):63-71
90. Misra UK, Tan CT, Kalita J (2008) Viral encephalitis and epilepsy. Epilepsia 49(Suppl 6):13-18

91. Miya K, Takahashi Y, Mori H (2014) Anti-NMDAR autoimmune encephalitis. Brain Dev 36:645-652

92. Morin-Brureau M, Lebrun A, Rousset MC, Fagni L, Bockaert J, de Bock F, Lerner-Natoli M (2011) Epileptiform activity induces vascular remodeling and zonula occludens 1 downregulation in organotypic hippocampal cultures: role of VEGF signaling pathways. J Neurosci 31:10677-10688

93. Nash TE, Mahanty S, Loeb JA, Theodore WH, Friedman A, Sander JW, Singh G, Cavalheiro E, Del Brutto OH, Takayanagui OM, Fleury A, Verastegui M, Preux PM, Montano S, Pretell EJ, White AC Jr, Gonzales AE, Gilman RH, Garcia HH (2015) Neurocysticercosis: a natural human model of epileptogenesis. Epilepsia 56:177-183

94. Ngoungou EB, Koko J, Druet-Cabanac M, Assengone-ZehNguema Y, Launay MN, Engohang E, Moubeka-Mounguengui M, Kouna-Ndouongo P, Loembe PM, Preux PM, Kombila M (2006) Cerebral malaria and sequelar epilepsy: first matched case-control study in Gabon. Epilepsia 47:2147-2153

95. Ngoungou EB, Dulac O, Poudiougou B, Druet-Cabanac M, Dicko A, Mamadou TA, Coulibaly D, Farnarier G, Tuillas M, Keita MM, Kombila M, Doumbo OK, Preux PM (2006) Epilepsy as a consequence of cerebral malaria in area in which malaria is endemic in Mali, West Africa. Epilepsia 47:873-879

96. Ngoungou EB, Bhalla D, Nzoghe A, Darde ML, Preux PM (2015) Toxoplasmosis and epilepsy-systematic review and meta analysis. PLoS Negl Trop Dis 9:e0003525

97. Ngugi AK, Bottomley C, Kleinschmidt I, Sander JW, Newton CR (2010) Estimation of the burden of active and life-time epilepsy: a meta-analytic approach. Epilepsia 51:883-890

98. Ngugi AK, Bottomley C, Kleinschmidt I, Wagner RG, Kakooza-Mwesige A, Ae-Ngibise K, Owusu-Agyei S, Masanja H, Kamuyu G, Odhiambo R, Chengo E, Sander JW, Newton CR (2013) Prevalence of active convulsive epilepsy in subSaharan Africa and associated risk factors: cross-sectional and case-control studies. Lancet Neurol 12:253-263

99. Niehusmann P, Mittelstaedt T, Bien CG, Drexler JF, Grote A, Schoch S, Becker AJ (2010) Presence of human herpes virus 6 DNA exclusively in temporal lobe epilepsy brain tissue of patients with history of encephalitis. Epilepsia 51:2478-2483

100. Noe FM, Polascheck N, Frigerio F, Bankstahl M, Ravizza T, Marchini S, Beltrame L, Bandero CR, Löscher W, Vezzani A (2013) Pharmacological blockade of IL-1beta/IL-1 receptor type 1 axis during epileptogenesis provides neuroprotection in two rat models of temporal lobe epilepsy. Neurobiol Dis 59:183-193

101. Oostenbrink R, Moons KG, Derksen-Lubsen G, Grobbee DE, Moll HA (2002) Early prediction of neurological sequelae or death after bacterial meningitis. Acta Paediatr 91:391-398

102. Osborn MK, Steinberg JP (2007) Subdural empyema and other suppurative complications of paranasal sinusitis. Lancet Infect Dis 7:62-67

103. Pal DK, Carpio A, Sander JW (2000) Neurocysticercosis and epilepsy in developing countries. J Neurol Neurosurg Psychiatry 68:137-143

104. Pernhorst K, Herms S, Hoffmann P, Cichon S, Schulz H, Sander T, Schoch S, Becker AJ, Grote A (2013) TLR4, ATF-3 and IL8 inflammation mediator expression correlates with seizure frequency in human epileptic brain tissue. Seizure 22:675-678

105. Pion SD, Kaiser C, Boutros-Toni F, Cournil A, Taylor MM, Meredith SE, Stufe A, Bertocchi I, Kipp W, Preux PM, Boussinesq M (2009) Epilepsy in onchocerciasis endemic areas: systematic review and meta-analysis of population-based surveys. PLoS Negl Trop Dis 3:e461 
106. Pitkänen A, Engel J Jr (2014) Past and present definitions of epileptogenesis and its biomarkers. Neurotherapeutics 11:231-241

107. Pozo-Rosich P, Clover L, Saiz A, Vincent A, Graus F (2003) Voltage-gated potassium channel antibodies in limbic encephalitis. Ann Neurol 54:530-533

108. Quattrocchi G, Nicoletti A, Marin B, Bruno E, Druet-Cabanac M, Preux PM (2012) Toxocariasis and epilepsy: systematic review and meta-analysis. PLoS Negl Trop Dis 6:e1775

109. Quet F, Guerchet M, Pion SD, Ngoungou EB, Nicoletti A, Preux PM (2010) Meta-analysis of the association between cysticercosis and epilepsy in Africa. Epilepsia 51:830-837

110. Ramanathan S, Mohammad SS, Brilot F, Dale RC (2014) Autoimmune encephalitis: recent updates and emerging challenges. J Clin Neurosci 21:722-730

111. Ravizza T, Boer K, Redeker S, Spliet WG, van Rijen PC, Troost D, Vezzani A, Aronica E (2006) The IL-1beta system in epilepsy-associated malformations of cortical development. Neurobiol Dis 24:128-143

112. Ravizza T, Gagliardi B, Noe F, Boer K, Aronica E, Vezzani A (2008) Innate and adaptive immunity during epileptogenesis and spontaneous seizures: evidence from experimental models and human temporal lobe epilepsy. Neurobiol Dis 29:142-160

113. Reid AY, Riazi K, Campbell TG, Pittman QJ (2013) Increased excitability and molecular changes in adult rats after a febrile seizure. Epilepsia 54:e45-e48

114. Riazi K, Galic MA, Pittman QJ (2010) Contributions of peripheral inflammation to seizure susceptibility: cytokines and brain excitability. Epilepsy Res 89:34-42

115. Riazi K, Galic MA, Kentner AC, Reid AY, Sharkey KA, Pittman QJ (2015) Microglia-dependent alteration of glutamatergic synaptic transmission and plasticity in the hippocampus during peripheral inflammation. J Neurosci 35:4942-4952

116. Rojas A, Jiang J, Ganesh T, Yang MS, Lelutiu N, Gueorguieva P, Dingledine R (2014) Cyclooxygenase-2 in epilepsy. Epilepsia 55:17-25

117. Saiz A, Blanco Y, Sabater L, Gonzalez F, Bataller L, Casamitjana R, Ramio-Torrenta L, Graus F (2008) Spectrum of neurological syndromes associated with glutamic acid decarboxylase antibodies: diagnostic clues for this association. Brain 131:2553-2563

118. Sander JW, Perucca E (2003) Epilepsy and comorbidity: infections and antimicrobials usage in relation to epilepsy management. Acta Neurol Scand Suppl 180:16-22

119. Sander JW (2004) Infectious agents and epilepsy. In: Knobler S, O'Connor S, Lemon SM, Najafi M (eds) The infectious etiology of chronic diseases: defining the relationship, enhancing the research and mitigating the effects. The National Academies Press, Washington, pp 93-99

120. Seebohm G, Piccini I, Strutz-Seebohm N (2015) Paving the way to understand autoantibody-mediated epilepsy on the molecular level. Front Neurol 6:149

121. Serpa JA, White AC Jr (2012) Neurocysticercosis in the United States. Pathog Glob Health 106:256-260

122. Shorvon S, Guerrini R (2010) Acute symptomatic seizuresshould we retain the term? Epilepsia 51:722-723

123. Silverman MA, Misasi J, Smole S, Feldman HA, Cohen AB, Santagata S, McManus M, Ahmed AA (2013) Eastern equine encephalitis in children, Massachusetts and New Hampshire, USA, 1970-2010. Emerg Infect Dis 19:194-201

124. Singhi $P$ (2011) Infectious causes of seizures and epilepsy in the developing world. Dev Med Child Neurol 53:600-609

125. Solimena M, Folli F, Denis-Donini S, Comi GC, Pozza G, De Camilli P, Vicari AM (1988) Autoantibodies to glutamic acid decarboxylase in a patient with stiff-man syndrome, epilepsy, and type I diabetes mellitus. N Engl J Med 318:1012-1020
126. Stewart KA, Wilcox KS, Fujinami RS, White HS (2010) Development of postinfection epilepsy after Theiler's virus infection of C57BL/6 mice. J Neuropathol Exp Neurol 69:1210-1219

127. Striano P, Perruolo G, Errichiello L, Formisano P, Beguinot F, Zara F, Striano S (2008) Glutamic acid decarboxylase antibodies in idiopathic generalized epilepsy and type 1 diabetes. Ann Neurol 63:127-128

128. Stringer JL (2006) Models available for infection-induced seizures. In: Pitkänen A, Schwartzkroin PA, Moshé SL (eds) Models of seizures and epilepsy. Elsevier, Burlington, pp 521-526

129. Tsunoda I, Fujinami RS (1996) Two models for multiple sclerosis: experimental allergic encephalomyelitis and Theiler's murine encephalomyelitis virus. J Neuropathol Exp Neurol 55:673-686

130. Tsunoda I, Fujinami RS (2010) Neuropathogenesis of Theiler's murine encephalomyelitis virus infection, an animal model for multiple sclerosis. J Neuroimmune Pharmacol 5:355-369

131. Uludag IF, Duksal T, Tiftikcioglu BI, Zorlu Y, Ozkaya F, Kirkali G (2015) IL-1beta, IL-6 and IL1Ra levels in temporal lobe epilepsy. Seizure 26:22-25

132. Umpierre AD, Remigio GJ, Dahle EJ, Bradford K, Alex AB, Smith MD, West PJ, White HS, Wilcox KS (2014) Impaired cognitive ability and anxiety-like behavior following acute seizures in the Theiler's virus model of temporal lobe epilepsy. Neurobiol Dis 64:98-106

133. Verboon-Maciolek MA, Krediet TG, Gerards LJ, Fleer A, van Loon TM (2005) Clinical and epidemiologic characteristics of viral infections in a neonatal intensive care unit during a 12-year period. Pediatr Infect Dis J 24:901-904

134. Verboon-Maciolek MA, Krediet TG, Gerards LJ, De Vries LS, Groenendaal F, van Loon AM (2008) Severe neonatal parechovirus infection and similarity with enterovirus infection. Pediatr Infect Dis J 27:241-245

135. Vezzani A, Moneta D, Conti M, Richichi C, Ravizza T, De Luigi A, De Simoni MG, Sperk G, Andell-Jonsson S, Lundkvist J, Iverfeldt K, Bartfai T (2000) Powerful anticonvulsant action of IL-1 receptor antagonist on intracerebral injection and astrocytic overexpression in mice. Proc Natl Acad Sci 97:11534-11539

136. Vezzani A, Balosso S, Maroso M, Zardoni D, Noe F, Ravizza T (2010) ICE/caspase 1 inhibitors and IL-1beta receptor antagonists as potential therapeutics in epilepsy. Curr Opin Investig Drugs 11:43-50

137. Vezzani A, Maroso M, Balosso S, Sanchez MA, Bartfai T (2011) IL-1 receptor/toll-like receptor signaling in infection, inflammation, stress and neurodegeneration couples hyperexcitability and seizures. Brain Behav Immun 25:1281-1289

138. Vezzani A, Friedman A (2011) Brain inflammation as a biomarker in epilepsy. Biomark Med 5:607-614

139. Vezzani A, Friedman A, Dingledine RJ (2013) The role of inflammation in epileptogenesis. Neuropharmacology 69:16-24

140. Vezzani A, Aronica E, Mazarati A, Pittman QJ (2013) Epilepsy and brain inflammation. Exp Neurol 244:11-21

141. Vezzani A, Viviani B (2015) Neuromodulatory properties of inflammatory cytokines and their impact on neuronal excitability. Neuropharmacology 96:70-82

142. Vezzani A (2015) Anti-inflammatory drugs in epilepsy: does it impact epileptogenesis? Expert Opin Drug Saf 14:583-592

143. Vooturi S, Jayalakshmi S, Sahu S, Mohandas S (2014) Prognosis and predictors of outcome of refractory generalized convulsive status epilepticus in adults treated in neurointensive care unit. Clin Neurol Neurosurg 126:7-10

144. Weinberg MS, Blake BL, McCown TJ (2013) Opposing actions of hippocampus TNFalpha receptors on limbic seizure susceptibility. Exp Neurol 247:429-437 
145. Wenceslau CF, McCarthy CG, Goulopoulou S, Szasz T, NeSmith EG, Webb RC (2013) Mitochondrial-derived $N$-formyl peptides: novel links between trauma, vascular collapse and sepsis. Med Hypotheses 81:532-535

146. Winkler AS (2012) Neurocysticercosis in sub-Saharan Africa: a review of prevalence, clinical characteristics, diagnosis, and management. Pathog Glob Health 106:261-274

147. Winkler AS, Friedrich K, Velicheti S, Dharsee J, Konig R, Nassri A, Meindl M, Kidunda A, Muller TH, Jilek-Aall L, Matuja W, Gotwald T, Schmutzhard E (2013) MRI findings in people with epilepsy and nodding syndrome in an area endemic for onchocerciasis: an observational study. Afr Health Sci 13:529-540

148. Xiong ZQ, Qian W, Suzuki K, McNamara JO (2003) Formation of complement membrane attack complex in mammalian cerebral cortex evokes seizures and neurodegeneration. J Neurosci 23:955-960

149. Zattoni M, Mura ML, Deprez F, Schwendener RA, Engelhardt B, Frei K, Fritschy JM (2011) Brain infiltration of leukocytes contributes to the pathophysiology of temporal lobe epilepsy. J Neurosci 31:4037-4050

150. Zhang Q, Tanaka K, Sun P, Nakata M, Yamamoto R, Sakimura K, Matsui M, Kato N (2012) Suppression of synaptic plasticity by cerebrospinal fluid from anti-NMDA receptor encephalitis patients. Neurobiol Dis 45:610-615

151. Zurolo E, Iyer A, Maroso M, Carbonell C, Anink JJ, Ravizza T, Fluiter K, Spliet WG, van Rijen PC, Vezzani A, Aronica E (2011) Activation of Toll-like receptor, RAGE and HMGB1 signalling in malformations of cortical development. Brain 134:1015-1032 